\title{
Stećci na području Dubrovačkoga primorja - nove spoznaje
}

Domagoj Perkić

Dubrovački muzeji

Arheološki muzej

E-pošta: domagoj.perkic@gmail.com
UDK: 726.825:904(497.5)

904:726.825(497.5)

Izvorni znanstveni rad

Primljeno: 27. veljače 2020

Prihvaćeno: 10. lipnja 2020

\section{Sažetak}

Rad donosi nove, ažurirane, topografsko-statističke podatke o lokalitetima sa stećcima na dubrovačkom području, s posebnim naglaskom na područje današnje, administrativne, općine $\mathrm{Du}$ brovačko primorje te rezultate arheoloških istraživanja lokaliteta Novakovo greblje u Čepikućama. Kroz navedena istraživanja utvrđeno je postojanje groblja sa stećcima u razdoblju od sredine 13. do u drugu polovicu 15. st., s tim da je isti položaj korišten kao groblje već u 8.-9. st. Po završetku arheoloških radova obavljena je konzervacija i restauracija svih stećaka.

Ključne riječi: stećci; Dubrovačko primorje; Čepikuće; Novakovo greblje; topografija; arheološko istraživanje; konzervacija.

* Članak je bio predviđen za objavu u okviru Zbornika o stećcima i Šefiku Bešlagiću 2015. godine. Na žalost, kako nikada nije došlo do realizacije navedenoga zbornika, ovdje se donosi ažurirani i dopunjeni rad. Sažetak predavanja izložen je na skupu: "Stećci u 21. stoljeću - nove spoznaje i mogućnosti interpretacije", održanom 17. listopada 2019. u Mostaru. 
Općina Dubrovačko primorje nalazi se zapadno od Grada Dubrovnika te istočno i južno od granice Bosne i Hercegovine s Hrvatskom. Kao zasebna općina osnovana je 1997. godine izdvajanjem iz Grada Dubrovnika. ${ }^{1}$ Područje općine izduženo je u pravcu sjeverozapad-jugoistok u dužini oko $40 \mathrm{~km}$, a širina mu se kreće od 5 do $15 \mathrm{~km}$. Prema postojećem teritorijalnom ustroju površina općine je $197,8 \mathrm{~km}^{2}$ ili 11,1\% teritorija Dubrovačko-neretvanske županije. ${ }^{2}$ Općinu čini 20 naselja: Banići, Kručica, Čepikuće, Doli, Imotica, Lisac, Majkovi, Mravinca, Ošlje, Podgora, Podimoč, Slano, Smokovljani, Stupa, Štedrica, Točionik, Topolo, Trnova, Trnovica i Visočani. ${ }^{3} \mathrm{O}$ administrativnim podjelama ovoga prostora, kako u vrijeme Dubrovačke Republike, tako i kasnije te uvriježene podjele na: Gornja sela, Primorska sela, Slansko primorje i Stonsko primorje, pisalo se u više navrata. ${ }^{4}$

Dubrovačko područje u kontekstu stećaka poznato je u starijoj literaturi već od kraja 19. st., prije svega kroz radove Vida Vuletića Vukasovića u Viestniku Hrvatskoga arkeološkoga društva ${ }^{5}$ i Starohrvatskoj

1 Ružica MišKović, "Općina Dubrovačko primorje - nova jedinica lokalne samouprave", u: Zbornik Dubrovačkog primorja i otoka, VII., Dubrovnik, 1999., str. 10-13.

2 Helena Karlić Mujo, "Suvremeni demografski i razvojni izazovi Općine Dubrovačko Primorje, Hrvatska", u: Geoadria, 15/1, Zadar, 2010., str. 110-111.

3 H. Karlić Mujo, "Suvremeni demografski i razvojni izazovi", str. 111.

4 Josip Lučić, "Stjecanje, dioba i borba za očuvanje Dubrovačkog Primorja 1399.-1405.", u: Arhivski vjesnik, XI.-XII., Zagreb, 1968.-1969., str. 11; ANA KAZNAČIĆ-HrDALO, "Dioba i ubikacija dijelova Slanskog primorja u doba pripojenja Dubrovniku godine 1399.", u: Anali Zavoda za povijesne znanosti istraživačkog centra JAZU u Dubrovniku, XVII., Dubrovnik, 1979., str. 17; ANA Hrdalo, "Kroz prošlost i sadašnjost Dubrovačkog primorja", u: Dubrovački horizonti, 21, Zagreb, 1981., str. 63.

5 Vid Vuletić-Vukasović, "Dopisi", u: Viestnik Hrvatskoga Arkeologičkoga družtva (dalje: VHAD), god. IV., br. 1, Zagreb, 1882., str. 23-26; Isti, "Dopisi", u: VHAD, god. VII., br. 2, 4, Zagreb, 1885., str. 55-59, 121-124; Isti, "Dopisi", u: VHAD, god. IX., br. 1, Zagreb, 1887., str. 121-124; IsTI, "Dopisi", u: VHAD, god. X., br. 4, Zagreb, 1888., str. 124-126; Isti, "Dopisi", u: VHAD, god. XI., br. 1, 2, Zagreb, 1889., str. 16-19, 56-60; Istı, "Starobosanski nadpisi u Bosni i Hercegovini", u: VHAD, god. XII., br. 1, 3, Zagreb, 1890., str. 5-7, 84-88; IsTI, "Razne viesti, Starohrvatski natpis u Konavlima", u: VHAD, god. XIII., br. 4, Zagreb, 1891., str. 121; IsTI, "Dopisi", u: VHAD, god. XIII., br. 3, Zagreb, 1891., str. 83-86; Isti, "Starobosanski nadpisi u Bosni i Hercegovini", u: VHAD, god. XIII., br. 4, Zagreb, 1891., str. 108-114; IstI, "Starobosanski nadpisi u Bosni i Hercegovini", u: VHAD, god. XIV., br. 1, Zagreb, 1892., str. 4-7. 
prosvjeti, ${ }^{6}$ a nešto manje i Frane Radića. ${ }^{7}$ U razdoblju između Drugoga svjetskog rata i Domovinskoga rata 1991. o stećcima su pisali: Alojz Benac, ${ }^{8}$ Josip Lučić, ${ }^{9}$ Cvito Fisković, ${ }^{10}$ Dubravka Beritić, ${ }^{11}$ a prvi topografski pregled donio je Šefik Bešlagić. ${ }^{12}$ Bogato ukrašen stećak s natpisom iz Brotnjica u Konavlima jedini je koji je privukao nešto više pažnje u stručnoj javnosti. ${ }^{13}$ Povremene spomene o pojedinim motivima sa stećaka dubrovačkoga područja donosi i Marian Wenzel. ${ }^{14} \mathrm{U}$ razdoblju nakon Domovinskoga rata o stećcima s područja Konavala u više navrata piše Zdenko Žeravica s koautorima, ${ }^{15}$ a o

6 Vid Vuletić-Vukasović, "Stećci u selu Popovićima u Konavlima", u: Starohrvatska prosvjeta, god. I., Knin, 1895., str. 237-238; Isti, "Stećci u Konavlima u Dalmaciji", u: Starohrvatska prosvjeta, god. II., Knin, 1896., str. 103-104; "Bibliografija", u: Starohrvatska prosvjeta, god. III., br. 3, 4, Knin, 1897., str. 161-162.

7 Frane Radić, "Razne viesti", u: Starohrvatska prosvjeta, god. III., br. 1, Knin, 1897., str. 42.

8 Alojz Benac, "Srednjovjekovni stećci od Slivna do Čepikuća", u: Anali Historijskog instituta JAZU u Dubrovniku, II., Dubrovnik, 1953., str. 59-85.

9 JosıP Lučić, "Stećci u Dubrovačkoj rijeci i Brgatu", u: Prilozi povijesti umjetnosti u Dalmaciji, 13, Split, 1961., str. 176-187.

10 Cvito Fisković, "Stećci u Cavtatu i u Dubrovačkoj župi", u: Prilozi povijesti umjetnosti u Dalmaciji, 13, Split, 1961., str. 147-174.

11 Dubravka Beritić, "Susret sa spomenicima kulture Dubrovačkog primorja (zapadni dio)", u: Zbornik Dubrovačkog primorja i otoka, I., Dubrovnik, 1986., str. 413-439; IsTA, "Rasprostranjenost stećaka na dubrovačkom području", u: Igor Fisković (prir.), Zbornik radova sa Simpozija Likovna kultura Dubrovnika 15. i 16. stoljeća, Dubrovnik, 1987., str. 145-149.

12 ŠEFIK BeŠLAGIĆ, Stećci, kataloško-topografski pregled, Biblioteka Kulturno naslijeđe, Veselin Masleša, Sarajevo, 1971., str. 87-96.

13 Marko Vego, "Ćirilski natpis u Brotnjicama u Konavlima", u: Prilozi povijesti umjetnosti u Dalmaciji, 13, Split, 1961., str. 188-191; ŠEFIK BEŠLAGIĆ, "Stećci u Brotnjicama", u: Anali Historijskog instituta JAZU u Dubrovniku, VIII.-IX., Dubrovnik, 1962., str. 65-83; D. BERITIĆ, "Rasprostranjenost", str. 146.

14 Marian Wenzel, Ukrasni motivi na stećcima, Biblioteka Kulturno naslijeđe, Veselin Masleša, Sarajevo, 1965., T XI., 7,8.; T XII., 5.; T XV., 10-13; T XXV, 9; T XXVIII., 17.

15 Zdenko ŽeraviCA - Ljiljana Kovačić, Konavle, srednjovjekovna groblja, Dubrovački muzeji, Dubrovnik, 2002.; ZDEnko ŽERaviCA, "Arheološka iskopavanja srednjovjekovnih nekropola u Konavlima tijekom 1997.-1999. godine", u: Zbornik Dubrovačkih muzeja, I., Dubrovnik, 2004., str. 283-330; IsTI, "Sv. Mihajlo, Gornja Čajkovica, Šumet", u: Hrvatski arheološki godišnjak, 1, Ministarstvo kulture RH, Zagreb, 2005., str. 254-256; Istı, "Križevi kao simbol kršćanstva na srednjovjekovnim kamenim nadgrobnim spomenicima - 
konavoskim stećcima u okviru općenitoga pregleda lokaliteta kulturne baštine i Julijana i Mato Brautović. ${ }^{16}$ Stećke Župe dubrovačke ${ }^{17}$ i Dubrovačkoga primorja ${ }^{18}$ kao i detaljni i ažurirani topografski pregled stećaka i drugih kasnosrednjovjekovnih nadgrobnih spomenika na dubrovačkom području donosi Domagoj Perkić u okviru izložbe "Stećci" i pripadajućem katalogu iz 2008. ${ }^{19}$ Gotovo 11 godina nakon toga, nakon brojnih novih rekognosciranja, izrade foto i nacrtne te 3D fotogrametrijskih modela pojedinih stećaka, Domagoj Perkić u izdanjima Dubrovačkih muzeja, publicira stećke na zapadnom dubrovačkom području, odnosno između grada Dubrovnika i granice s BiH kod Neuma. ${ }^{20}$

U obje spomenute publikacije iz 2008. i 2019., osim stećaka obrađeni su i drugi nadgrobni spomenici, prije svega srednjovjekovne nadgrobne ploče i nadgrobni učelci, s tim da su u ovoj potonjoj detaljno objašnjene njihove razlike od stećaka. ${ }^{21}$

U kontekstu povijesnoga pregleda proučavanja stećaka, općenito na dubrovačkom području, nezaobilazno je naglasiti pokretanje multinacionalne nominacije te izradbe Pristupnoga popisa (Tentativne liste) za upis stećaka na Popis svjetske kulturne baštine UNESCO-a. ${ }^{22}$

mramori (tzv. stećci) u Konavlima", u: Ivo Lučıć (prir.), Zbornik Hum i Hercegovina kroz povijest, I., Zagreb, 2011., str. 331-401.

16 Julijana Antić Brautović - Mato Brautović, Povijesno-umjetnička topografija Konavala i stanje očuvanosti spomeničke baštine, Udruga mladih Konavala, Močići, 2005.

17 Domagoj Perkić - Marta Perkić, "Lokaliteti", u: Arheološka baština Župe Dubrovačke, Katalog izložbe, Dubrovnik, 2007., str. 34-35, 42, 55, 59; DoмAGOJ PERKić, "Stećci na području Župe Dubrovačke, nijemi svjedoci povijesti", Kurenat, 4, Župa Dubrovačka, 2008., str. 15-16.

18 Domagoj Perkić, "Nove spoznaje o grobljima sa stećcima na području Čepikuća i Trnovice", u: Zbornik Dubrovačkih muzeja, II., Dubrovnik, 2013., str. 17-45.

19 Ivan Alduk - Domagoj Perkić - Marinko Tomasović, "Topografija stećaka u Hrvatskoj", u: Jasmina PoklečKi Stošić (prir.), Stećci, katalog izložbe, Zagreb, 2008., str. 58-120.

20 Domagoj Perkić, Stećci i drugi kasnosrednjovjekovni nadgrobni spomenici zapadnoga dubrovačkog područja, Dubrovnik, 2019.

21 D. Perkić, Stećci i drugi kasnosrednjovjekovni nadgrobni spomenici, str. 15-17.

22 Dana 15. srpnja 2016., na 40. zasjedanju UNESCO-ovog Odbora za svjetsku baštinu u Istanbulu u Turskoj, nominacija Stećci - srednjovjekovna groblja nadgrobnih spomenika upisana je na Popis svjetske baštine UNESCO-a. 
S područja Hrvatske izabrana su samo dva lokaliteta koja su zadovoljavala stroge kriterije UNESCO-a: Cista Velika - Velika i Mala Crljivica, Općina Cista Provo i crkva sv. Barbare sa stećcima u Općini Konavle. $^{23}$

Na temelju postojeće literature, a posebice obavljenih rekognosciranja terena autora ovoga rada i dokumentiranja kasnosrednjovjekovnih nadgrobnjaka, može se reći da na Dubrovačkom području stećke nalazimo na gotovo cijelom teritoriju nekadašnje Dubrovačke Republike, izuzevši sve otoke, poluotok Pelješac i uže urbano područje Grada. Dakle, možemo ih pratiti na području Općine Konavle (24 lokaliteta s 588 stećaka), Općine Župa dubrovačka (4 lokaliteta s 21 stećkom), administrativnom području grada Dubrovnika od Šumeta na istoku do Dubravice i Riđice na zapadu (10 lokaliteta sa 68 stećaka) i Dubrovačkom primorju (29 lokaliteta s 362 stećka). Ukupno bi to bilo 67 lokaliteta s 1039 stećaka. ${ }^{24}$

Primjetno je da je iz ovakvih statističkih podataka izostavljen poluotok Pelješac, iako je u starijoj literaturi spominjan kao područje s brojnim stećcima. Možda najbolji primjer zašto je tomu tako jest podatak kako je u Stonu nekada bilo više od 500 stećaka o čemu prvi spomen donosi N. Z. Bjelovučić 1921. godine. ${ }^{25}$ Takvu informaciju, odnosno pogrješku, prenosi i Bešlagić, ${ }^{26}$ a prenosim je i sam kod pisanja topografije za izložbu "Stećci" 2008. ${ }^{27}$ Uvidom u stanje na terenu kao i detaljnim iščitavanjem literature utvrđeno je da Bjelovučić kada govori o 500 stećaka u Stonu misli na lokaciju kod Crkve sv. Kuzme i Damjana. No, on takvu vijest prenosi tek na osnovu pričanja lokalnoga stanovništva, navodeći kako je većina stećaka uništena početkom 20. st., kod gradnje sadašnjega groblja pa je već tada bilo vidljivo samo 25 ploča u ogradama groblja i neposredno u međama ispod. ${ }^{28} \mathrm{U}$ međuvremenu o nadgrobnjacima uokolo crkve sv. Kuz-

23 O stećcima na Sv. Barbari vidjeti u: Domagoj Perkić, "Stećci kod crkve sv. Barbare u Dubravci, Konavle", u: Zbornik Dubrovačkih muzeja, 4, Dubrovnik, 2017., str. 67-138.

24 D. PERKić, Stećci i drugi kasnosrednjovjekovni nadgrobni spomenici, str. 200.

25 Nikola Zvonimir Bjelovučić, Povijest poluotoka Rata (Pelješca), Split, 1921., str. 53, 74.

26 Š. BEŠLAGIĆ, Topografski pregled, str. 88.

27 I. Alduk - D. Perkić - M. Tomasović, "Topografija", str. 101, 103.

28 N. Z. Bjelovučić, Povijest, str. 74. 
me i Damjana pišu V. Sokol ${ }^{29}$ (spominje tek dvije nadgrobne ploče ukrašene motivima tordiranoga užeta i urezanim Tau križem) i C. Fisković $^{30}$ (spominje općenito nadgrobne ploče i učelke). Uvidom na terenu utvrđeno je postojanje samo 5 cjelovitih nadgrobnih učelaka s reljefnim prikazom križa. Svi su ugrađeni kao spolije u ziđu stubišta i crkve. Nije vidljiva niti jedna izvorna srednjovjekovna nadgrobna ploča, a kamoli stećak. Slična situacija je i s ostalim dijelovima Pelješca gdje zapravo nemamo niti jedan stećak, nego tek nadgrobne učelke i nadgrobne ploče s prikazima štita i mača, ali koje nisu stećci.

\section{Novakovo greblje u Čepikućama}

Na prostoru naselja Čepikuće u općini Dubrovačko primorje nalaze se tri lokaliteta sa stećcima: oko Crkve sv. Martina, Dobrštak i predmetno Novakovo greblje. Postoje mišljenja kako je riječ o jednom, naknadno dislociranom lokalitetu, no to se vjerojatno može reći samo za položaj Dobrštak, dok su položaji oko Crkve sv. Martina i Novakovo greblje vjerojatno zasebni lokaliteti. Razlog tako veliku broju lokaliteta sa stećcima kao i samih stećaka možemo tražiti u smještaju Čepikuća na prirodnoj komunikaciji od priobalja ka unutrašnjosti, odnosno od Slanog i Dola prema Trebinji i Ravnom, u postojanju Crkve sv. Martina (moguće još iz ranosrednjovjekovnog razdoblja) ${ }^{31}$ te zbog blizine izvora vode Dobrštak.

Takav položaj uz komunikacije je veoma čest smještaj za groblja sa stećcima. Naime, postavljanje grobova i groblja uz komunikacije je običaj koji možemo pratiti od prapovijesnih, preko antičkih pa sve do srednjovjekovnih razdoblja. Komunikaciju možemo promatrati kao simbolični put na drugi svijet ili možemo pretpostaviti vjerovanje i želju da mrtvi predci čuvaju putnike i put kao pristup naselju. Kako su komunikacije sve donedavno zapravo bile prije svega prirodne komunikacije, koje su prilagođene tadašnjim potrebama, gro-

29 Vladimir Sokol, "Kasnosrednjovjekovna grobišta i nadgrobni spomenici Pelješca", u: Pelješki zbornik, 1, Zagreb, 1976., str. 332.

30 Cvito Fisković, "Stećci u Cavtatu i u Dubrovačkoj župi", u: Prilozi povijesti umjetnosti u Dalmaciji, 13, Split, 1961., str. 152; IstI, "Likovna baština Stona", u: Anali JAZU, XXII.-XXIII., Zagreb, 1985., str. 96.

31 Igor Fisković, "Crkveno graditeljstvo dubrovačke regije u svjetlu povijesti, od IX. do XII. stoljeća", u: Želimir Puljić - Nediljko A. Ančić (prir.) Tisuću godina Dubrovačke (Nad)biskupije, Dubrovnik, 2001., str. 413. 
blja uz njih nalazimo u obliku kamenih gomila, raznih vrsta rimskih nekropola, pa tako i groblja uz crkve i groblja sa stećcima.

Blizinu vode (lokve, izvori, bunari) kao čest čimbenik izbora smještaja stećaka moguće je promatrati kroz prizmu kontinuiteta kultnog, svetog mjesta, ali i kroz čisto profane razloge što su takva mjesta često posjećivana u svakodnevnom životu. ${ }^{32} \mathrm{Na}$ području Dubrovačkoga primorja takve položaje lokaliteta nalazimo u Trnovi (Greblje) i Gornjim Majkovima (Crkva sv. Stjepana), ${ }^{33}$ a u Župi dubrovačkoj kod Petrače (Crkva sv. Đurđa). ${ }^{34}$ U obližnjem Popovu (Bosna i Hercegovina) stećke uz vodu nalazimo u Strujićima, Veličanima, Starom Slanom, Humu i Ravnom. ${ }^{35}$

Novakovo greblje nalazi se na povišenom položaju na zaravni između Lisca i Cepikuća, oko 330 m južno od Crkve sv. Martina i naselja Čepikuće i $200 \mathrm{~m}$ južno od položaja Dobrštak i istoimenog izvora, na k.č. 1288, k.o. Čepikuće (slika 1). Središnje koordinate položaja po Gaus - Kriegeru su: X = 4744824 N; Y $=6486984$ E, Z = 251,70 m NV (prilog 1). U stručnoj literaturi Novakovo greblje obrađivano je u više navrata. ${ }^{36}$ Uglavnom se daju osnovni podatci o broju stećaka te se raspravlja o ukrasima koji se javljaju na njima. Takvi radovi nastali su temeljem obilaska lokaliteta i opisa onoga što se moglo vidjeti, s tim da je potrebno naglasiti kako je dio stećaka bio okrenut i nisu bili vidljivi svi ukrasi (slika 2,3).

32 IvAn Alduk, "Stećci u kontekstu europskog i našeg srednjovjekovlja", u: JASMina PoklečKi Stošić (prir.), Stećci, katalog izložbe, Zagreb, 2008., str. 47.

33 I. Alduk - D. Perkić - M. Tomasović, "Topografija", str. 105-106.

34 I. Alduk - D. Perkić - M. Tomasović, "Topografija", str. 107; Marta Perkić, "Rezultati arheoloških istraživanja kod Crkve sv. Đurđa u Petrači", u: Zbornik Župe Dubrovačke, V., Zagreb, 2008., str. 103; IstA, "Rezultati arheoloških istraživanja kod crkve sv. Đurđa u Župi dubrovačkoj", u: Starohrvatska prosvjeta, vol. III., No. 35, Split, 2008., str. 65; D. PER Kić - M. PER Kić, "Lokaliteti", str. 32-37.

35 Šefix Bešlagić, Popovo, Srednjovjekovni nadgrobni spomenici Bosne i Hercegovine, sv. VIII., Zavod za zaštitu spomenika kulture Bosne i Hercegovine, Sarajevo, 1966., str. 90.

36 V. Vuletić-Vukasović, "Dopisi", 1885., str. 122; A. Benac, "Srednjovjekovni stećci", str. 73-74; D. Beritić, "Susret sa spomenicima", str. 425-427; Š. BEŠLAGIĆ, Topografski pregled, str. 90; I. Alduk - D. Perkić - M. Tomasović, "Topografija", str. 105; D. PERKIć, Stećci i drugi kasnosrednjovjekovni nadgrobni spomenici, str. 74-81. 
Prvi ozbiljniji radovi, koji su donijeli neke nove spoznaje, obavljeni su 2011., financiralo ih je Ministarstvo kulture, a obuhvatili su čišćenje terena od raslinja, podizanje i okretanje 2 stećka dizalicom, izrada geodetskoga situacijskog snimka, izrada arhitektonskoga snimka postojećeg stanja, dokumentacija 4 stećka - crteži i 3D skeniranje 2 stećka. ${ }^{37}$ Dakle, riječ je o isključivo dokumentacijskim radovima kao podloga i priprema za daljnja istraživanja. Međutim, i takvim radovima dobivene su nove spoznaje koje su se prije svega odnosile na nove ukrase, odnosno nove motive koji nisu bili vidljivi u prijašnjem položaju stećaka. Takve spoznaje rezultirale su zasebnom objavom. ${ }^{38}$

Sljedeći nivo radova, obavljen 2013., obuhvaćen je projektom "HER. CUL" - Valorizacija kulturne baštine srednjovjekovnih stećaka na zapadnom Balkanu. Riječ je o projektu Europske unije koji se financira iz programa pod nazivom "Preparatory actions for preserving and restoring cultural heritage in conflict areas in the Western Balkans for the year 2010 - EUROPEAID/131266/C/ACT/MULTI". Nositelj projekta je Regionalna razvojna agencija Dubrovačko-neretvanske županije DUNEA. ${ }^{39}$ U okviru navedenoga projekta obavljena su: arheološka iskopavanja većeg dijela lokaliteta ${ }^{40}$ (uključujući analizu osteoloških nalaza - antropološka analiza i DNA analiza, ${ }^{41} \mathrm{C}-14$ datiranje ${ }^{42}$ konzervacija i restauracija pokretnih arheoloških nalaza, ${ }^{43}$

37 Izvođač arheoloških radova bila je tvrtka Arheoplan d.o.o., a kao podizvođači tvrtke Habitat geo d.o.o., (geodetska podloga) i NEIR d.o.o. (3D skeniranje dva stećka).

38 D. Perkić, "Čepikuće i Trnovica", str. 17-45.

39 Domagoj Perkić - Ivan Alduk - Joško ĆAleta, Stazama stećaka, Katalog izložbe, DUNEA, Dubrovnik, 2014.; Domagoj Perkić - Ivan Alduk - MaRijana Aksić Vitković - Marija Radovanović, Stazama stećaka, Katalog projekta HER.CUL, Dunea, Dubrovnik, 2014.

40 Arheološka istraživanja obavila je tvrtka ARHEO PLAN d.o.o, Butkovina 7, 20216 Dubravka, voditeljica istraživanja Konstanta Mucić, dipl. arheolog, zamjenica Nela Kovačević Bokarica, dipl. arheolog.

41 Antropološka i DNA analiza uzoraka izvršene su u Antropološkom laboratoriju KBC-a Split, Udruga "Hrvatski identitet", predsjednik udruge prof. dr. sc. Šime Anđelinović, antropološka obrada: Tina Bareša, mag. for., Ivana Anterić, dipl. arh., prof. fil. Krešimir Sučić, dr. med.

42 C 14 analiza obavljena je na Beta Analytic Radiocarbon Data Labaratory iz Miamija, SAD.

43 Obavio izv. prof. Ivo Donelli, restaurator-savjetnik, Odsjek za restauracijukonzervaciju Umjetničke akademije Sveučilišta u Splitu. 
crtanje pokretnih nalaza, ${ }^{44}$ video dokumentiranje ${ }^{45}$ ) te konzervacija i restauracija svih stećaka. ${ }^{46}$

Prije nego se prikažu rezultati arheoloških istraživanja iz 2013., zbog cjelovitosti i lakšeg razumijevanja konteksta ovoga lokaliteta sa stećcima, donijet će se osnovni podatci o lokalitetu s kataloškim opisom svih stećaka. Ovdje se ne će raspravljati o ukrasnim motivima na stećcima jer je o tome relativno nedavno već pisano. ${ }^{47}$

Novakovo greblje predstavlja jedno od najvažnijih, ali i najočuvanijih srednjovjekovnih grobalja sa stećcima na širem dubrovačkom području. Sadrži 6 stećaka, od čega su četiri ukrašena, a dva nisu. U tipološkom smislu imamo: 1 sljemenjak bez podnožja, tri visoka sanduka i dva obična sanduka. ${ }^{48}$ Većina stećaka bila je okrenuta, a kako su kasnija istraživanja pokazala i dislocirana u odnosu na izvorni grob. Lokalitet je djelomično devastiran u novom vijeku: u sjeverozapadnom dijelu, za vrijeme austrijske vladavine, ukopana je mjerna točka (trigonometar), a nešto dalje je iskopan i natrag vraćen dio zemlje (oko $3 \mathrm{~m}^{2}$, navodno prilikom "vježbanja" u radu s bagerom lokalnog stanovništva). Negdje 60-ih godina prošlog stoljeća, oko stećaka je podignut kameni prsten u suhozidnoj tehnici relativne visine od oko $30 \mathrm{~cm}$, no ni on nije sačuvan u cijelosti.

Kataloški opis stećaka:

STeĆAK 1 (tabla 1, slika 6, 7) - sljemenjak bez podnožja, dimenzija 182 x 83 x 109, odnosno $120 \mathrm{~cm}$, težina $6700 \mathrm{~kg}$. Prednja i stražnja dužinska stranica ukrašene su motivom arkadnih udubljenja, a iznad arkada je bordura u obliku vitice s trolistom. Na prednjoj bočnoj stranici nalazi se štit s mačem, mač ima kuglasti završetak, postavljen je vertikalno iza pravokutnog štita, a preko štita je dijagonalna traka što dijeli štit na dva jednaka trokutasta isječka. U gor-

44 Sve crteže pokretnog arheološkog materijala nacrtala je Mirna Jokić, dipl. arheolog.

45 Autor video dokumentacije Oliver Pezo, Udruga ArtFormat iz Dubrovnika.

46 Obavio je izv. prof. Ivo Donelli, restaurator-savjetnik s timom suradnika, Odsjek za restauraciju-konzervaciju Umjetničke akademije Sveučilišta u Splitu.

47 D. Perkić, "Čepikuće i Trnovica", str. 21-23.

48 Pri određivanju tipova stećaka pridržavalo se uobičajene tipologije gdje su sanduci svi stećci viši od $30 \mathrm{~cm}$, iako prema ukupnom dojmu stećci 2 i $6 \mathrm{mogu}$ biti i ploče. 
njem isječku je polumjesec, a u donjem zvijezda. Cijeli motiv štita s mačem omeđen je bordurom u obliku tordiranog užeta, a u gornjem dijelu i vitice s trolistom koja prati tordirano uže i balčak mača. $\mathrm{Na}$ stražnjoj bočnoj stranici je konjanik s kopljem, a uz rub bordura u obliku tordiranog užeta.

STEĆAK 2 - sanduk dimenzija 166 x 89 x 47 cm, težina $2300 \mathrm{~kg}$, bez bilo kakvih ukrasa na svim stranicama.

STEĆAK 3 (tabla 3:1-3) - visoki sanduk dimenzija 205 x 79 x $116 \mathrm{~cm}$, težina $4500 \mathrm{~kg}$. Dvije bočne (južna i sjeverna) i jedna uzdužna (istočna) stranica jednako su ukrašene bordurom u obliku vitice $s$ trolistom uz gornji rub stećka, ispod koje je motiv tordiranog užeta koji prati gornje i bočne rubove stećka. Druga uzdužna (zapadna) stranica nije vidljiva, ali se može pretpostaviti isti ukras. Gornja površinska stranica nije ukrašena.

STEĆAK 4 (tabla 2, slika 8) - visoki sanduk dimenzija 181 x 78 x 71 $\mathrm{cm}$, težina $2700 \mathrm{~kg}$. Na prednjoj uzdužnoj (zapadnoj) stranici prikaz je scene lova: konjanik s kopljem u ruci ispred kojeg je prikaz jelena, sve je uokvireno bordurom u vidu tordiranog užeta iznad kojega je motiv vitica s trolistom. Na prednjoj bočnoj (južnoj) stranici je prikaz dviju heraldički postavljenih ptica (grlica ?), odnosno motiv euharistije (bez kaleža), iznad kojeg je opet ista bordura, tj. tordirano uže i vitice s trolistom. Stražnja uzdužna (istočna) stranica ukrašena je samo bordurom u vidu tordiranog užeta koji prati gornje i bočne rubove stećka, a ispod gornjeg ruba je motiv vitice s trolistom. Stražnja bočna (sjeverna) stranica ima isti ukras kao i stražnja uzdužna. Na gornjoj stranici nalazi se prikaz pravokutnog štita s mačem, mač ima kuglasti završetak, preko štita je dijagonalna traka što dijeli štit na dva jednaka trokutasta isječka. U gornjem isječku je polumjesec, a u donjem zvijezda (kao na bočnoj stranici stećka 1). Pokraj vrha mača s kuglom nazire se prikaz rozete (?).

STEĆAK 5 (tabla 3:4-7) - sanduk dimenzija 177 x 77 x $78 \mathrm{~cm}$, težina $2700 \mathrm{~kg}$. Sve bočne i uzdužne stranice jednako su ukrašene bordurom u obliku vitice s trolistom uz gornji rub stećka, ispod koje je motiv tordiranog užeta koji prati gornje i bočne rubove stećka. Na istočnoj uzdužnoj stranici naknadno su urezana slova R B A, što su navodno inicijali osobe Rabadžija Baldo pokojnog Ante. Gornja površinska stranica nije ukrašena.

STEĆAK 6 - sanduk dimenzija 184 x 94 x 30-40 cm, težina $2050 \mathrm{~kg}$, bez bilo kakvih ukrasa na svim stranicama. 


\section{Rezultati arheoloških istraživanja $2013 .^{49}$}

Prije obavljanja arheoloških istraživanja svi stećci su dislocirani na obližnji položaj kako bi se mogao istražiti cijeli prostor veličine oko 17 x $14 \mathrm{~m}$ (dakle oko $238 \mathrm{~m}^{2}$ ). S obzirom da se dislociranje obavljalo auto dizalicom, bilo je moguće izmjeriti i težinu svakoga pojedinog stećka što je navedeno u kataloškom opisu stećaka.

Iskopavanje je u cijelosti obavljeno ručnim iskopom, vodeći računa o stratigrafiji, tj. proučavanju arheoloških slojeva-stratigrafskih jedinica, s ciljem da ih se poreda u kronološkom i kulturnom redoslijedu, odvajajući pojedine stratigrafske jedinice i nalaze unutar njih.

Utvrđeno je da je površinski sloj na lokalitetu bio humus i recentni kameni nasip. Sljedeći otkopni sloj bio je zemljani sloj u kojem su pronađeni srednjovjekovni grobovi. Relativna visina kamenog nasipa iznosila je oko $0,40 \mathrm{~m}$, a zemljanog sloja od oko 0,20 do oko 0,70 m. Završni sterilni sloj je kamen živac (tzv. mujara) i zemlja zdravica svijetlosmeđe i sive boje (tzv. bjelica). Ukupno je pronađeno 6 grobova koji pripadaju dvjema fazama sahranjivanja (prilog 2 i prilog 3 ).

\section{FAZA 1}

Prva, ranija faza sahranjivanja pripada ranosrednjovjekovnom razdoblju i ona je u potpunosti uništena kasnijim grobljem sa stećcima, odnosno drugom fazom. Od prve faze preostala je tek nakupina kostiju, koja je definirana kao grob 1, te ostatci kamenoga prstena - obruba koji je evidentiran sa sjeveroistočne i jugozapadne strane lokaliteta.

Ovaj obrub pripisan je prvoj fazi zbog visinski nižeg položaja u odnosu na grobove sa stećcima, a vjerojatno je označavao ukopni prostor ranosrednjovjekovne faze ukopavanja. Rađen je od većeg i srednjeg pločastog kamena vodoravno postavljenog na zemlju zdravicu i kamen živac.

49 Za pisanje dijela članka o rezultatima arheoloških istraživanja iz 2013. korišten je Završni izvještaj: restauratorski i konzervatorski radovi, arheološko istraživanje, na lokalitetu Novakovo greblje, Čepikuće, Dubrovnik, 2013., autora: Konstante Mucić i Nele Kovačević Bokarica, uz njihovu suglasnost, na čemu im i ovom prilikom zahvaljujem. 
Groв 1 smješten je u centralnom dijelu lokaliteta, neposredno ispod površine i jedne amorfne kamene ploče. Riječ je, zapravo, o veliku broju dislociranih, polomljenih i na hrpu nabacanih kostiju, bez ikakve grobne arhitekture, odnosno riječ je o sekundarnom položaju ostataka grobova na koje se naišlo prilikom kopanja grobova druge faze. Dimenzije pronađene nakupine kostiju su oko: $1,35 \mathrm{~m}$ (dužina) x $1,00 \mathrm{~m}$ (širina) x 0,35 m (dubina). Antropološkom analizom utvrđeno je da se ovdje nalazi najmanje 10 individua, od čega 6 muškaraca (20-50 godina), 2 žene (35-44 godine), 1 dijete (3-4 godine) i 1 osoba kojoj nije bilo moguće odrediti spol. Datiranjem C-14 metodom uzorka kostiju iz groba 1 dobivena je apsolutna datacija u razdoblju 710.- 890. god. posl. Kr., s 95 \% vjerojatnosti.

\section{FAZA 2}

Druga faza sahranjivanja predstavlja vrijeme ukopavanja pod stećcima. Ukupno je pronađeno 5 grobova (grobovi 2-6), s tim da je jedino grob 4 moguće vezati uza stećak 1, dok sve ostale grobove nije moguće direktno vezati uz pojedine stećke, jer su stećci toliko dislocirani u odnosu na grobove, da je mogućnost pogrješke u eventualnom pridruživanju groba stećku veoma velika. Osim toga, primjetno je da nedostaje jedan grob (6 stećaka, 5 grobova), što je vjerojatno posljedica devastiranosti lokaliteta u njegovu sjeverozapadnom dijelu.

Svi grobovi građeni su u sustavu grobne škrinje od više slabo obrađenih i priklesanih kamenih ploča, gdje se one okomito postavljene nazivaju obložnica, a one vodoravne poklopnica. Grobne konstrukcije nalaze se do najviše $50 \mathrm{~cm}$ od današnje površine ili pliće. Njihova očuvanost varira tako da su grobovi 2, 3 i 5 dobro očuvani, a 4 i 6 loše ili samo djelomično. Zapuna kod svih grobova je rahla zemlja smeđe boje s većom primjesom manjeg i sitnog kamena. Dno groba je zemlja zdravica i kamen živac. Veličina grobnih konstrukcija je u prosjeku 190-220 cm dužine, $20-60 \mathrm{~cm}$ širine te $30-70 \mathrm{~cm}$ dubine.

Orijentacija grobova ove faze nije u potpunosti ujednačena, iako je načelno istok - zapad, s tim da je glava na zapadu. Naime, grobovi 2 , 3 i 5 orijentirani su sjeverozapad - jugoistok, grob 4 jugozapad - sjeveroistok te grob 6 zapad - istok (vidi prilog 2 i 3).

Uobičajeno, u svim grobovima nalaze se isključivo kosturni ukopi, $\mathrm{u}$ ispruženom položaju na leđima, s prekriženim rukama na trbuhu (barem kod onih grobova gdje je stanje očuvanosti kostura dopuštalo takvu konstataciju - grobovi 2, 3 i 6, dok je kod grobova 4 i 5 očuva- 
nost loša pa ne možemo biti sigurni). Vrlo često pokojnici sahranjeni pod stećcima imaju prekrižene ruke na trbuhu ili grudima, npr. na lokalitetu Grborezi kod Livna od ukupno 218 grobova (gdje se mogao utvrditi položaj ruku), u njih 120 pokojnici imaju tako prekrižene ruke ${ }^{50}$ ili na lokalitetu Stećci u Raškoj gori kod Mostara gdje od 97 grobova 42 pokojnika imaju prekrižene ruke. ${ }^{51}$ Inače, u ikonografiji prikaz pokojnika s prekriženim rukama tipičan je znak pripadnosti kršćanskoj vjeri. ${ }^{52}$

Broj ukopa u pojedinom grobu varira. Samo jedan grob (grob 4, ispod stećka 1) predstavlja pojedinačni ukop, dok su dva groba s dvojnim ukopom (grobovi 2 i 3), a dva s višestrukim ukopima (grob 5 sa 7 individua i grob 6 s 3 individue). Dakle, prema provedenoj antropološkoj analizi, u drugoj fazi ukupno je ukopano najmanje 15 individua, od čega 9 muškaraca i 6 žena. Svi su bili sahranjeni pod stećcima, što donekle odudara od uobičajene prakse. Naime, iako odnos broja grobova pod stećcima i onih bez stećaka nije ujednačen, gotovo uvijek je znatno više grobova nego stećaka. Možemo navesti samo nekoliko primjera sa šireg dalmatinskog prostora gdje su (sustavno) istraživana groblja sa stećcima: groblje pod Borinovcem kod Trilja imalo je 25 stećaka i 57 grobova, ${ }^{53}$ u Poljanicama u Bisku 2 stećka i 28 grobova, ${ }^{54} \mathrm{u}$ Ričicama kod Imotskog (lokaliteti Pratrova glavica i Parlovi) 50 stećaka i 141 grob, ${ }^{55}$ u Opletju kod Koteza (blizu Vrgorca)

50 ŠEFIK BEŠLAGIĆ, Grborezi, srednjovjekovna nekropola, Zavod za zaštitu spomenika kulture SR BiH, Sarajevo, 1964., str. 64.

51 Vukosava Atanacković-Salčić, "Zaštitno arheološko istraživanje srednjovjekovne nekropole Stećci u Raškoj gori kod Mostara", u: Naše starine, XVIII.XIX., Sarajevo, 1989., str. 93-94.

52 Dubravko Lovrenović, Stećci, Bosansko i humsko mramorje srednjeg vijeka, Naklada Ljevak, Zagreb, 2013., str. 117; više o ležećim prikazima pokojnika s prekriženim rukama na stećcima vidi u: Dimitrije Sergejevski, "Slike pokojnika na našim srednjevjekovnim nadgrobnim spomenicima", u: Glasnik Zemaljskog muzeja u Sarajevu, n.s. VIII., Sarajevo, 1953., str. 131-144.

53 Ante Milošević, "Kasnosrednjovjekovna nekropola sa stećcima pod Borinovcem u Trilju", u: Starohrvatska prosvjeta, III. ser., sv. 12, Split, 1982., str. 195.

54 Ante MilošEvić, Stećci i Vlasi: stećci i vlaške migracije 14. i 15. stoljeća u Dalmaciji i jugozapadnoj Bosni, Regionalni zavod za zaštitu spomenika kulture u Splitu, Split, 1991., str. 40.

55 Vanja Kovačić - Žıvko Mikić - Nikola Jakšić - Goran Nikšić, Ričice - nekropole stećaka, Regionalni zavod za zaštitu spomenika kulture, Split, 1983. str. 61-62. 
9 stećaka i 47 grobova, ${ }^{56}$ na Vučipolju - Crkvina kod Dugopolja 70 stećaka i 179 grobova, ${ }^{57}$ na tumulu 1 u Eracima (Istočna Plina) kod Ploča 7 stećaka i 16 grobova ${ }^{58}$ te na položaju Krč, također u Eracima 3 stećka i 7 grobova. ${ }^{59}$ Vidimo da je u prosjeku odnos stećaka i grobova 1:3, odnosno broj grobova koji nisu pod stećcima je u prosjeku i do tri puta veći.

Također upada u oči odnos u spolnosti ukopanih osoba pri čemu je na ovom groblju sahranjeno više muškaraca nego žena, dok je na većini drugih kasnosrednjovjekovnih grobalja u Dalmaciji, znatno češće, obratno. ${ }^{60}$

Uz datiranje C-14 metodom uzorka kosti iz groba 1 (1. faza), datiranje ovom metodom obavljeno je na još 7 uzoraka iz pet grobova 2. faze. ${ }^{61}$ Kada je riječ o višestrukim ili dvojnim ukopima, uvijek se nastojalo uzeti uzorak iz zadnje sahranjene individue (obično sačuvani kostur) te po jedan uzorak od starijih ukopa čije su kosti obično gurnute $\mathrm{u}$ dno groba. Kada kompariramo C-14 analize, odnosno datiranje, s provedenom antropološkom analizom, dobivamo sljedeću situaciju:

Groв 2 (prilog 4) (2 individue)

- 1 muškarac (40-49 god.) (datacija 1300.-1420.)

- 1 žena (više od 35 god.)

56 Ante Milošević, "Srednjovjekovna groblja na položaju Opletje u Bunini podno Koteza kod Vrgorca", u: Marinko Tomasović (prir.), Arheološka istraživanja na trasi autoceste u Zabiokovlju i Plini, Gradski muzej Makarska, Makarska, 2011., str. 216, 221, 226.

57 Hrvoje Gjurašın, "Vučipolje - Crkvine (r.b. 222)", u: Hrvatski arheološki godišnjak, 2, Ministarstvo kulture RH, Zagreb, 2005., str. 422-423.

58 Marinko Tomasović, "Ograde - tumul, Eraci (r.b. 269)", u: Hrvatski arheološki godišnjak, 4, Ministarstvo kulture RH, Zagreb, 2007., str. 577-580; IsTI, "Kasnosrednjovjekovno groblje u tumulu 1 na Ogradi (Dražice) u Eracima (Istočna Plina)", u: Marinko Tomasović (prir.), Arheološka istraživanja na trasi autoceste u Zabiokovlju i Plini, Gradski muzej Makarska, Makarska, 2011., str. 289, 307.

59 Maja Bilić - Ante Ivišıć - Šime Vulić, "Arheološka istraživanja u Istočnoj Plini s posebnim osvrtom na groblja kasnog srednjeg vijeka", u: MARINKo Tomasović (prir.) Arheološka istraživanja na trasi autoceste u Zabiokovlju i Plini, Gradski muzej Makarska, Makarska, 2011., str. 263-264.

60 V. KovačIĆ - Ž. Mikić - N. JAKŠıć - G. NikšIĆ, Ričice, str. 61-68.

61 Kod svih datiranja uzimana je 2 sigma kalibracija gdje je raspon u datiranju nešto veći, ali je veća i vjerojatnost točnosti od $95 \%$. 
Groв 3 (prilog 5) (2 individue)

- 1 muškarac (17-22 god.) (datacija 1280.-1390.), mlađi ukop

- 1 muškarac (više od 50 god.) (datacija 1220.-1280.), stariji ukop, dislociran uz rub groba

Grob 4 (prilog 6) (1 individua)

- žena (30-39 god.) (datacija 1300.-1400.)

Grob 5 (prilog 7 ) (7 individua)

- 1 individua, zadnji ukop, najmlađi (datacija 1420.-1460.)

- 6 individua dislocirano uz rub (datacija 1300.-1420.)

- 5 muškaraca (dva 17-24 god., dva 30-39 i jedan 45-54 god.)

- 2 žene (20-24 god. i 30-39)

Groв 6 (prilog 8) (3 individue)

- 1 individua, neodređenog spola (18-24 god.), zadnji ukop, najmlađi (datacija 1400.-1440.)

- 1 muškarac (25-39 god.) i 1 žena (30-39 god.), stariji ukopi, dislocirani uz rub groba

Što se tiče DNA analize kojom se nastojala utvrditi eventualna rodbinska povezanost između individua unutar istog groba ili unutar cijelog groblja, ona na žalost nije uspjela. Naime, uzeti su uzorci od 7 različitih ukopa iz svih grobova, analiza se dva puta ponavljala, no ni za jedan uzorak nije dobiven puni parcijalni profil koji bi omogućio interpretaciju DNA rezultata. Prema izvještaju udruge "Hrvatski identitet", s Antropološkoga laboratorija pri KBC-u Split razlog nedobivanja rezultata jest nedostatna količina jezgrene DNA u uzorcima.

Nakon završetka samog arheološkog iskopa cijeli lokalitet prekriven je s geotekstilom i zatrpan zemljom, a svi stećci vraćeni su na svoj izvorni (ili pretpostavljeni izvorni) položaj, odnosno iznad grobova (prilog 9, slika 4, 5).

Konzervacija i restauracija svih stećaka obavljena je prije povrata na lokalitet. O svim radovima napravljen je zaseban izvještaj u okviru završnoga izvješća projekta. ${ }^{62}$ Detaljan opis takvih radova ovdje nije prikazan, jer izlazi izvan okvira i struke autora članka. Ukratko

62 Ivo Donelli, "Restauratorski i konzervatorski radovi", u: Završni izvještaj: restauratorski i konzervatorski radovi, arheološko istraživanje, na lokalitetu Novakovo greblje, Čepikuće, Dubrovnik, 2013., str. 14-20. 
se može reći da su obavljena sva potrebna uzorkovanja radi utvrđivanja količine štetnih soli u kamenu, uzorkovanja lišajeva, zatim su stećci oprani vodom pod tlakom te očišćeni biocidnim sredstvima od bioloških nakupina. Potom je obavljeno konsolidiranje strukture kamena i sanacija pukotina te na kraju rekonstrukcija nedostajajućih dijelova (samo na onim mjestima gdje se zadržava voda - pukotine) uz tonsko ujednačavanje rekonstruiranih dijelova.

\section{Pokretni arheološki nalazi (Tabla 4)}

Tijekom arheoloških istraživanja pronađen je i manji broj pokretnih nalaza. Međutim, rijetke od njih možemo vezati uz fazu sahranjivanja pod stećcima, a još manje uz pojedine grobove. Tako iz prapovijesnih razdoblja imamo 7 ulomaka keramičkih posuda koje nije moguće dovesti u direktni kontekst s lokalitetom (u blizini postoji više gradinskih lokaliteta i kamenih gomila). Novom vijeku pripadaju 3 numizmatička nalaza (austrijski novac u nominalama filler i kreutzer, od kraja 18. do početka 20. st.).

Kasnom srednjem vijeku, dakle vremenu stećaka, možemo pripisati jedan ulomak trbuha keramičke posude, te po jedan nož, čavao, brončani privjesak i pojasnu kopču. Međutim, i oni nisu nađeni direktno na ostatcima skeleta, nego ili izvan groba ili unutar zapune groba.

\section{Katalog - posebni nalazi}

PN 1 (Tabla 4:1) - željezni nož, mjesto nalaza: sloj zemlje (SJ 1) između grobova 1 i 2 .

Opis: sječivo i drška izrađeni od željeza (dim. 8,70x1,80-80x0,20 cm). $\mathrm{Na}$ dršci je očuvana zakovica kojom je željezni dio bio spojen $s$ koricama drške. Može pripadati nožu manjih dimenzija ili britvi.

PN 2 (Tabla 4:2) - željezni čavao, mjesto nalaza: zapuna groba 3.

Opis: djelomično očuvani čavao (duž. $3,50 \mathrm{~cm}$ ), izrađen kovanjem. Glavica mu je spljoštena, nepravilnog polukružnog oblika i pravokutnog presjeka (dim. 1,50-0,50 cm). Tijelo mu je spljošteno i ima pravokutni presjek (dim. 0,55x0,25 cm). Vrh čavla nedostaje.

PN 3 (Tabla 4:3) - privjesak od brončanog lima, mjesto nalaza: zapuna groba 5. 
Opis: privjesak (dim. 2,70x1,40-0,85x0,10 cm). Izrađen je savijanjem lima rađenoga od slitine bakra (bronce). Ima nepravilni cjevasti oblik, te s jedne strane kružni, a s druge polukružni presjek.

PN 4 (Tabla 4:4) - željezna kopča, mjesto nalaza: grob 1.

Opis: kopča (dim. 7,10x2,70-1,70x0,8-0,6 cm). Izrađena je lijevanjem od željeza. Pređica joj je ovalnoga oblika i presjeka (dim. $2,85 \times 2,60 \times 0,50 \mathrm{~cm})$. Jezičac ima zašiljen vrh. Okov je pravokutnoga oblika (dim. 1,85x1,45x0,80 cm).

\section{Narodna tradicija i stećci na Novakovu greblju}

Već sam toponim upućuje na izvjesne prežitke kulturne memorije lokalnoga stanovništva, a koji se odnose na ovaj lokalitet i same stećke. Naime, postoje dvije osnovne inačice narodne predaje koje se djelomice prožimaju, ali i razlikuju. Prema prvoj, ${ }^{63}$ na Novakovu greblju pokopan je Novak Novaković, junak iz Trnovice (obližnje naselje, oko $5 \mathrm{~km}$ sjeverno od Čepikuća) koji je ustao protiv Dubrovačke Republike i poginuo, te je pokopan pod sljemenjakom (stećak 1). Prema drugoj, ${ }^{64}$ Novak Novaković bio je pripadnik višega staleža iz srednje Bosne koji se pred Turcima zajedno sa širom obitelji povlači na područje Dubrovačkoga primorja, odnosno Čepikuća. Predaja dalje kaže da je on bio pravoslavne vjere, za razliku od obitelji Pasarića koji također potječu iz srednje Bosne, ali su katoličke vjere. Već u svojoj izvornoj postojbini te se dvije obitelji često sukobljavaju, ali sukobi se nastavljaju i na prostoru Čepikuća, gdje su Pasarići izgradili poznatu kulu Pasarića, koja se i danas tamo nalazi. Pasarići su kupili i cijelu župu Lisac od plemića Koljenovića Dobrštaka, a Novakovići su podigli kulu negdje na Neretvi. Do sukoba dolazi vjerojatno zbog vjerskih razloga, ali prije svega zbog opće prevlasti i oko zemlje. Prva bitka dogodila se na prostoru Trnovice, a druga na Dobrštaku, gdje pogibaju Novak Novaković i njegovo šestero braće, te bivaju pokopani na lokalitetu koji dobiva naziv Novakovo greblje.

63 Don Josip Krstanović, "600 godina Župne crkve i 380 godina matične crkve Gospe od Rozarija u Liscu", u: Zbornik Dubrovačkog primorja i otoka, 3, Dubrovnik, 1991., str. 99; MATKo JeRinić, "Primorski krug pepelom", u: Zbornik Dubrovačkog primorja i otoka, 4, Dubrovnik, 1993., str. 89.

64 Nike Smojver, "Vojvoda Novak Novaković i bitka na Dobrštaku u Čepikućama", u: Zbornik Dubrovačkog primorja i otoka, 5, Dubrovnik, 1995., str. 413-414. 
U svakom slučaju, kod obje se inačice, kao eponimna osoba, javlja izvjesni Novak Novaković. Ne možemo sa sigurnošću govoriti o tome da li je on uopće bio povijesna osoba, a još manje ga dovoditi u točno određeni povijesni kontekst. Novakovići se kroz 14. i 15. st. vrlo često javljaju u raznim izvorima, uglavnom u zaleđu Dubrovačkoga primorja, a ponekad se izričito navode kao pripadnici Vlaha Bobana ${ }^{65}$ Novakoviće nalazimo i kasnije do u prvu polovicu 20. st., uglavnom na prostoru Popova u zaleđu Dubrovačkoga primorja. ${ }^{66}$

Međutim, provedena istraživanja pokazala su da ga najvjerojatnije ne možemo dovesti u direktni kontekst s ovim grobljem. Pod najljepšim stećkom (sljemenjak, stećak 1) očito je sahranjena žena, u trenutku smrti stara 30-39 godina, a ne Novak Novaković. On je imao šestero braće, dakle njih sedmero, a stećaka je ukupno 6. Osim toga, groblje je egzistiralo kroz najmanje dva stoljeća i očito nije nastalo u jednom trenutku. Također, ni predaja da je Novak Novaković bio pravoslavne vjere (što je navodno vidljivo na bočnoj stranici sljemenjaka gdje je konjanik s kopljem), ${ }^{67}$ pogotovo nema nikakve utemeljenosti. Naime, takve su scene česte na cijeloj rasprostranjenosti stećaka i ni na koji način ne mogu se dovesti u vezu s pravoslavljem ili sa Srbima.

Najvjerojatnije je narodna predaja posljedica potrebe lokalnoga stanovništva da si kroz legende objasni nastanak groblja i stećaka.

\section{Povijesni kontekst širega područja Čepikuća u kasnom sred- njem vijeku}

Razdoblje u kojem je nastalo i egzistiralo Novakovo greblje u Čepikućama (sredina 13. do sredine 15. st.) je inače vrlo važno u povijesti

65 Esad Kurtović, Vlasi Bobani, Društvo za proučavanje srednjovjekovne bosanske istorije, Sarajevo, 2013., str. 16, 19, 35, 42, 50; Isti, "Iz historije pčelarstva u srednjem vijeku (košnice, pčele i med na uzgoju i u pljačkama u Dubrovniku i dubrovačkom zaleđu)", u: Prilozi, 39, Sarajevo, 2010., str. 14; IsTi, "Uzgoj konja u dubrovačkom zaleđu kroz prizmu ugovora o uzgoju", u: Husnija Kamberović (prir.), Spomenica Ibrahima Karabegovića, Zbornik Radova, Institut za istoriju, Sarajevo, 2013., str. 61; Isti, "Selo Grebci u Popovu u srednjem vijeku", u: Radovi, Knjiga XIV.-XV., Sarajevo, 2010., str. 351.

66 Milenko Filipović - Ljubo MićEvić, Popovo u Hercegovini, Antropogeografski prikaz, Naučno društvo NR Bosne i Hercegovine, Djela, Knjiga XV., Odjeljenje istorisko filoloških nauka, Knjiga 11, Sarajevo, 1959., str. 192.

67 N. Smojver, "Vojvoda Novak Novaković", str. 413-414. 
Dubrovačkoga primorja. Naime, to je vrijeme neposredno pred, za vrijeme i nakon povijesnoga trenutka kada Dubrovačko primorje dolazi pod Dubrovačku Republiku 1399. godine. ${ }^{68}$ Težnja Dubrovnika za kupnju Primorja nisu neka posebna (prirodna) bogatstva, nego prije svega sigurnost trgovačkih putova. Stete od pljački bile su tolike da je dugoročno bilo jeftinije kupiti cijelo područje. ${ }^{69}$ Međutim, jedan od razloga zasigurno je bilo i zaustavljanje Osmanlija koji su nadirali prema Primorju, čime bi mogli prekinuti dubrovačke trgovačke veze i putove sa zaleđem, stvoriti probleme u funkcioniranju solane u Stonu, ali i uspostaviti svoje luke i carine što bi u mnogočemu smetalo Dubrovčanima. ${ }^{70}$ Jedan od razloga jest i sigurna kopnena veza sa Stonom i Pelješcem. ${ }^{71}$ Već 1396. godine Dubrovčani šalju poslanstva hrvatsko-ugarskom kralju Žigmundu s ciljem posredovanja kod velikaša Hrvoja Vukčića Hrvatinića, a on dalje kod tadašnje bosanske kraljice Jelene Grube i drugih bosanskih velikaša, oko ustupanja Primorja. ${ }^{72}$ To se, međutim, događa tek 3 godine poslije. Sam čin dolaska Primorja pod Dubrovačku Republiku ozakonjen je izdavanjem povelje bosanskog kralja Stjepana Ostoje 15. siječnja 1399., na Usori, kojom se Dubrovniku daruje čitavo Primorje od Dubrovnika (Kurila u Petrovu Selu) do Stona, zajedno sa svim naseljima, ljudima, vodama, pašama, šumama i svim ostalim. Zauzvrat Stjepan Ostoja dobiva 1500 dukata, kuću u Dubrovniku i postaje

68 Prema pojedinim autorima, područje Gruža, Rijeke dubrovačke, Zatona i Elafita prvotno je također bilo u sklopu Zahumlja, ali je znatno prije 1399. došlo pod Dubrovnik, o tome vidjeti u: PAVAo AnĐelić, "Srednjovjekovna župa Primorje u Humskoj zemlji", u: Srednjovjekovne humske župe, Mostar, 1999., str. 18-19. S druge strane, postoji mišljenje kako su ti prostori zajedno sa Šumetom i većim dijelom Župe dubrovačke ulazili u prvotni dubrovački teritorij, kao nasljedstvo epidaurskog agera, o tome vidjeti u: JosıP Lučić, Prošlost dubrovačke Astareje, Dubrovnik, 1970., str. 10-44.

69 Grga Čremošnik, "Prodaja Bosanskog Primorja Dubrovniku god. 1399. i kralj Ostoja", u: Glasnik Zemaljskog muzeja u Sarajevu, 40, Sarajevo, 1928., str. 110; Josip Lučić, "Prošlost Dubrovačkog primorja do dolaska pod Dubrovačku Republiku god. 1399.", u: Zbornik Dubrovačkog primorja i otoka, 1, Dubrovnik, 1986., str. 28.

70 J. Lučić, "Prošlost Dubrovačkog primorja", str. 29.

71 Josıp Lučıć, "Stjecanje, dioba i borba za očuvanje Dubrovačkog Primorja 1399-1405.", u: Arhivski vjesnik, XI.-XII., Zagreb, 1968.-1969., str. 116.

72 Ferdo Šıšić, Vojvoda Hrvoje Vukčić Hrvatinić i njegovo doba (1350.-1416.), pretisak 2004., Hrvoje Biblioteka, Zagreb, 2004., str. 126-127. 
dubrovačkim građaninom. ${ }^{73}$ Dio zemlje (po jedna desetina) u Primorju dobiva Stjepan Ostoja i Hrvoje Vukčić Hrvatinić koji također postaje dubrovačkim građaninom i dobiva palaču od 1500 dukata. ${ }^{74}$ Dakako, prošlo je i nekoliko godina dok Dubrovačka Republika nije u potpunosti stavila Primorje pod svoju upravu. U početku selo Lisac bilo je izuzeto iz darovnice jer je ono pripadalo vlastelinu Radič Sankoviću koji je odbio potpisati spomenutu darovnicu. Međutim, već iste godine, 25. kolovoza, on ipak predaje i Lisac, a zauzvrat dobiva 1500 perpera, biva primljen u Veliko vijeće i postaje dubrovačkim građaninom. ${ }^{75}$ Veliko vijeće 23. svibnja 1399. objavljuje odredbe o Primorju, o pravima starosjedilaca i drugim mjerama. Određuje se kako će se Primorje, odnosno kako se sada zove Terre Nove, podijeliti među vlastelom, a nešto malo i među građanima i Crkvom (po jedan solad $^{76}$ zemlje dobit će svaka od 15 crkvi koja se spominje u darovnici, a za potrebe groblja). Oko $83 \%$ dobila je vlastela, a $17 \%$ građani, s tim da nitko svoj dio nije dobio na jednom mjestu nego su čestice jednoga vlasnika bile razbacane po cijelom Primorju, a sve u namjeri da bi svatko dobio zemlju jednake poljoprivredne vrijednosti. Ovakva dioba ostala je na snazi nekoliko stoljeća, a zapisana je u posebni katastik (cathasticum) na pergameni. ${ }^{77}$ Čitavo primorje podijeljeno je na 29 desetina, a svaka desetina obuhvaća 322,4 solda zemlje. ${ }^{78}$ Pri ovakvoj podjeli zemlje potrebno je naglasiti kako bosanska vlastela ili vlasteličići, koje Dubrovčani nazivaju Basticis - Baštići (mali plemići - didići), nisu dobili nikakvu zemlju, odnosno njihova je zemlja jednostavno prisvojena. ${ }^{79} \mathrm{U}$ dokumentima dubrovačkoga Veli-

73 F. Šıšić, Vojvoda Hrvoje, str. 130-131; G. ČremošNik, "Prodaja Bosanskog Primorja", str. 119-120; J. Lučić, "Stjecanje, dioba i borba", str. 120; IsTi, "Prošlost Dubrovačkog primorja", str. 29-30.

74 G. Čremošnik, "Prodaja Bosanskog Primorja", str. 121, 124; J. Lučić, "Prošlost Dubrovačkog primorja", str. 30.

75 G. Čremošnık, "Prodaja Bosanskog Primorja", str. 126; J. Lučić, "Stjecanje, dioba i borba", str. 124; Isti, "Prošlost Dubrovačkog primorja", str. 30.

761 solad $=1678 \mathrm{~m}^{2}$.

77 J. Lučıć, "Prošlost Dubrovačkog primorja", str. 30.

78 J. LučIć, "Stjecanje, dioba i borba", str. 130.

79 G. Čremošnik, "Prodaja Bosanskog Primorja", str. 125; JosıP Lučıć, "Uprava u Dubrovačkom (Slanskom) primorju u doba Republike", u: Zbornik Dubrovačkog primorja i otoka, 1, Dubrovnik, 1986., str. 37. Termin didići, u značenju domaće, staro i izvorno plemstvo javlja se u brojnim pravnim dokumentima, npr. u Poljičkom statutu, opširnije vidi u: Mirko Klarić, "O Poljičkoj samo- 
kog vijeća vezanim uz kupnju Primorja 1399., umjesto vlasteličići, javlja se i termin baštići, a ponekad i çintiloti ${ }^{80}$ Termin dedić, didić, djedić zapravo je jednako kao baštić, kao što baština znači djedovina. ${ }^{81}$ Prema nekim izvorima, Dubrovčani su htjeli zadržati bosansku (humsku) vlastelu ako bi oni sami to htjeli, ali oni nisu pristali. No prema drugim izvorima (J. Restić, Chronica Ragusina, str. 185 i M. Orbini, Il regno de gli Slavi, str. 362), sva bosanska vlastela je protjerana. ${ }^{82}$ Zapravo, baštići su mogli ostati ako će postati seljaci i biti "ljudi" nekoga od dubrovačkih vlastelina. To je, naravno, izazvalo pobune, kako baštića tako i nekih seljaka, koji pale svoje kuće i imanja. Pobune su ubrzo ugušene, a tko nije htio "ostati" (pod opisanim uvjetima), biva protjeran, no mogao je ponijeti sa sobom stoku i druga pokretna dobra. ${ }^{83}$ Dana 8 . kolovoza 1399 . Veliko vijeće odlučilo je da se baštićima ne da zemlja, ${ }^{84}$ a 31 . listopada 1399. da moraju napustiti Primorje, osim ako ne žele postati kmetovi dubrovačke vlastele. ${ }^{85}$ Unatoč darovnici i zakonitoj primopredaji, svim potrebnim potpisima i suglasnostima bosanskoga kralja, vlastele i velmoža, Primorje nije u početku potpuno pod Dubrovnikom. Spominjani Radič Sanković od 1403. do 1404. okupira dio Primorja, i to sela Imoticu, Trnovicu i Lisac. Nakon Sankovićeve smrti ta sela preuzima Sandalj Hranić Kosača, ${ }^{86}$ a Dubrovčani ih dobivaju natrag tek 1405. poveljom Tvrtka II. Tvrtkovića. ${ }^{87}$ Nesuglasice oko Primorja traju sve do 1419. godine,

upravi", u: Zbornik radova Pravnog fakulteta u Splitu, god. 43, 2/2006., Split, 2006., str. 153; Jevgenij Paščenko, Od Kijeva do Poljica, Putovima prastarih migracija, Zagreb, 2010., str. 36-38.

80 Minajlo Dinić, Humsko-trebinjska vlastela, Srpska akademija nauka i umetnosti, Posebna izdanja 397, Odeljenje društvenih nauka, 54, Beograd, 1967., str. 89.

81 Isto.

82 G. Čremošnik, "Prodaja Bosanskog Primorja", str. 125.

83 J. Lučıć, "Uprava u Dubrovačkom primorju", str. 37.

84 J. Lučić, "Stjecanje, dioba i borba", str. 129.

85 Isto, str. 131.

86 O ulozi Sandalja Hranića i ponovo Hrvoja Vukčića Hrvatinića u završnoj predaji Lisca vidjeti u: Esad KurTović, Veliki vojvoda bosanski Sandalj Hranić Kosača, Sarajevo, 2009., str. 137-157.

87 Postoji mišljenje da su sela Imotica, Topolo, Stupa, Ošlje, Trnovica i zaljev Bistrina u početku bili dio župe Žaba, ali pripojeni su Dubrovniku zajedno s ostalim dijelovima župe Primorje, o tome vidjeti u: P. AnĐElić, "Srednjovjekovna župa Primorje", str. 19-21. 
kada Ostojin sin Stjepan Ostojić u Zvečaju potvrđuje Dubrovčanima sve stare povelje bosanskih vladara. Od tada je Dubrovačko primorje u potpunosti dio Dubrovačke Republike, a njegove nepromijenjene granice i danas su granica prema Bosni i Hercegovini. ${ }^{88}$

\section{Zaključak}

U kontekstu izrade kataloga izložbe "Stećci" upriličene u Klovićevim dvorima u Zagrebu, napisan je i članak "Topografija stećaka u Hrvatskoj", ${ }^{89}$ za potrebe čega je napravljeno detaljno rekognosciranje lokaliteta sa stećcima na širem Dubrovačkom području. Isto je nastavljeno u okviru projekta "HER.CUL" - Valorizacija kulturne baštine srednjovjekovnih stećaka na zapadnom Balkanu, čiji je nositelj Regionalna razvojna agencija Dubrovačko-neretvanske županije DUNEA. Navedeno je rezultiralo sastavljanjem nove, ažurne topografije lokaliteta sa stećcima na Dubrovačkom području. Zadnja, najsveobuhvatnija publikacija s detaljnom foto i nacrtnom dokumentacijom te 3D fotogrametrijskim modelima izabranih stećaka izašla je u izdanjima Dubrovačkih muzeja 2019. godine. ${ }^{90}$

U okviru spomenutoga projekta "HER.CUL", obavljena su i arheološka istraživanja i iskopavanja, te konzervacija i restauracija svih stećaka na lokalitetu Novakovo greblje u Čepikućama, općina Dubrovačko primorje. Riječ je o relativno malom, ali iznimno vrijednom i sačuvanom arheološkom lokalitetu sa stećcima. Zbog toga je i izabran za radove u okviru projekta "HER.CUL", jer je samo na takvu lokalitetu bilo moguće napraviti sve radnje potrebne na istraživanju, konzervaciji i prezentaciji, kako lokaliteta u cjelini, tako i svih pojedinih stećaka.

Arheološkim istraživanjima iz 2013. utvrđeno je kako je kasnosrednjovjekovno groblje sa stećcima smješteno na poziciji ranijeg groblja iz 8./9. st. posl. Kr. Od tog ranijeg groblja ostala je tek nakupina kostiju (od najmanje 10 individua) u centralnom dijelu lokaliteta (prilog 2 i 3).

Od groblja sa stećcima preostalo je 6 stećaka i 5 grobova, sa sveukupno 15 sahranjenih individua (većina grobova ima višestruke

88 J. Lučıć, "Stjecanje, dioba i borba", str. 138-140; Isti, "Prošlost Dubrovačkog primorja", str. 30.

89 I. Alduk - D. Perkić - M. Tomasović, "Topografija", str. 58-120.

90 D. PERKIĆ, Stećci i drugi kasnosrednjovjekovni nadgrobni spomenici. 
ukope). Prema rezultatima C-14 analize groblje je bilo u uporabi od prve polovice 13. st. do druge polovice 15. st. (oko 1220. do 1460. godine). Iako je ova faza manjim dijelom devastirana (nedostaje jedan grob, većina stećaka je dislocirana u odnosu na izvorni položaj), osim utvrđenoga početka i kraja sahranjivanja pod stećcima, došlo se do brojnih drugih podataka koji upotpunjuju poznavanje kulture stećaka na dubrovačkom području.

Tako je utvrđeno da je pod najvećim i najljepšim stećkom (stećak 1, Tabla 1), sljemenjakom, ukrašenim štitom i mačem te prikazom konjanika, zapravo sahranjena samo jedna žena, u trenutku smrti stara između 30 i 39 godina (grob 4, prilog 6). Osim toga, taj jedini grob pod sljemenjakom je C-14 analizom datiran u razdoblje između 1300. do 1400. godine (s $95 \%$ vjerojatnosti), što nam je vrijedan podatak jer u taj period možemo smjestiti i nastanak sljemenjaka. Do sada je obično smatrano kako sljemenjaci predstavljaju zadnju fazu u razvoju stećka, odnosno kako se počinju izrađivati tek tijekom 15. st. ${ }^{91}$

Vidjeli smo i da samo grob 4 predstavlja pojedinačni ukop pod stećkom, dok su svi ostali grobovi imali višestruke ukope (od dvije do sedam individua po jednom grobu).

Nadalje, temeljem rezultata antropološke analize, kao i datiranjem grobova iz ove druge faze groblja (pogotovo groba 4 ispod sljemenjaka, stećka 1), s velikom sigurnošću možemo tvrditi kako se u ovom slučaju narodna tradicija, odnosno legende o Novaku Novakoviću, ne mogu dovesti u čvrstu korelaciju sa stvarnim stanjem na terenu. Više je braće Novakovića spominjanih u legendi nego što ima stećaka (sedmero braće, šest stećaka), a tamo gdje je trebao ležati Novak Novaković leži žena koja je umrla u vrijeme prije nego što je Dubrovačko primorje došlo pod Dubrovačku Republiku.

Pitanje mogućega kontinuiteta sahranjivanja pod stećcima nakon što je pojedini prostor dospio pod Dubrovačku Republiku, također je riješeno. Naime, vrijeme 14. i 15. st., dakle najintenzivnijega sahranjivanja pod stećcima, je ujedno i vrlo turbulentno razdoblje na dubrovačkom prostoru kada se Republika širi na okolni prostor. Prvo je kupljen Ston s Pelješcem 1333., ${ }^{92}$ zatim Dubrovačko primor-

91 A. Milošević, Stećci i Vlasi, str. 45, bilješka 100; D. Lovrenović, Stećci, str. 66.

92 Izbor literature: Josıp Lučić, "Pelješac od dolaska Slavena do potpadanja pod vlast Dubrovačke Republike", u: Pelješki zbornik, 2, Dubrovnik, 1980., str. 5-72; Isti, "Najstarija zemljišna knjiga u Hrvatskoj - Dubrovački zemljišnik 
je 1399. ${ }^{93}$ te na kraju Konavle 1419., odnosno $1426 .{ }^{94}$ Uvriježeno je mišljenje da se pod stećcima sahranjuju samo oni koji su si to mogli i priuštiti u financijskom smislu. Poznat je podatak iz 1377. prema kojemu je cetinski Vlah Ostoja Bogović podmirio ukupne troškove sahrane Vlaha Priboja Papalića u iznosu od 40 libara (vjerojatno uključuje izradu ali i postavljanje stećka), što je ekvivalent cijeni cijele obiteljske grobnice u crkvi šibenskih franjevaca. ${ }^{95}$ Prema tome, logično je stećke povezati s lokalnim plemstvom. Međutim, što se s njima događa nakon 1399. i dolaska Primorja pod Republiku? Može li se na području Dubrovačkoga primorja očekivati sahranjivanje pod stećcima nakon 1399., ako imamo u vidu podatke o situaciji u kojoj se našla lokalna vlastela? Predmetnim istraživanjem utvrđeno je da su najmanje dva ukopa obavljena u 15. st. U grobu 5 najmlađi ukop datiran je u razdoblje od 1420. do 1460., a u grobu 6 od 1400. do 1440. godine. Dakle, iako je Novakovo greblje za sada jedino sustavno arheološki istraživano groblje pod stećcima na dubrovačkom području, s pravom se može pretpostaviti kako se sahranjivanje pod stećcima nastavlja neovisno o promjenama na vlasti i upravljanju pojedinim prostorima.

Nadamo se da su rezultati istraživanja i zaštite stećaka s Novakova greblja u Čepikućama opravdali njegov izbor za uključivanje u pro-

diobe zemlje u Stonu i Pelješcu iz god. 1336." u: Anali Zavoda za povijesne znanosti HAZU u Dubrovniku, 18, Dubrovnik, 1980., str. 57-89; PAvo GLunčIĆ, Iz prošlosti grada Stona XIV-XIX vijeka, Spomenik CXI, Odjeljenje društvenih nauka, nova serija 13, Beograd, 1961.; PAvo Žıvković, "Ustupanje Konavala Dubrovčanima", u: Konavle u prošlosti, sadašnjosti i budućnosti, 1, Dubrovnik, 1998., str. 77-99; Ante Marinović, Povijest razvitka srednjovjekovnoga dubrovačkog zemljišnika: crna knjiga o Astarei, Književni krug Split (Biblioteka znanstvenih djela, knj. 167), Split, 2013.

93 Izbor literature: J. Lučić, "Uprava u Dubrovačkom primorju", str. 35-55; IsTI, "Prošlost Dubrovačkog primorja", str. 11-34; Isti, "Stjecanje, dioba i borba", str. 99-201; G. Čremošnik, "Prodaja Bosanskog Primorja", str. 109-126; A. KAZNAČIĆ-Hrdalo, "Dioba i ubikacija", str. 17-47.

94 Izbor literature: Niko Kapetanić - Nenad Vekarić, Stanovništvo Konavala, 1, Zavod za povijesne znanosti HAZU, Dubrovnik - Zagreb, 1998., str. 23-33; RadoslaV GrujIć, Konavli pod raznim gospodarima od XII do XV veka, Spomenik SAN 66, Beograd, 1926., str. 12-13; Niko Kapetanić, Konavle u XV. stoljeću, Matica hrvatska Konavle, Gruda, 2011., str. 11-14.

95 A. Milošević, Stećci i Vlasi, str. 45, bilješka 100. 
jekt HER.CUL, kao i prethodne manje projekte, te da on zaista može biti ogledni primjer za ostale lokalitete sa stećcima.

U svakom slučaju, riječ je o iznimno vrijednim ostatcima kulturne baštine kasnoga srednjeg vijeka, koji u mnogočemu upotpunjuju spoznaje o kulturi stećaka, kako na dubrovačkom, tako i na širem području. 


\section{PRILOZI}

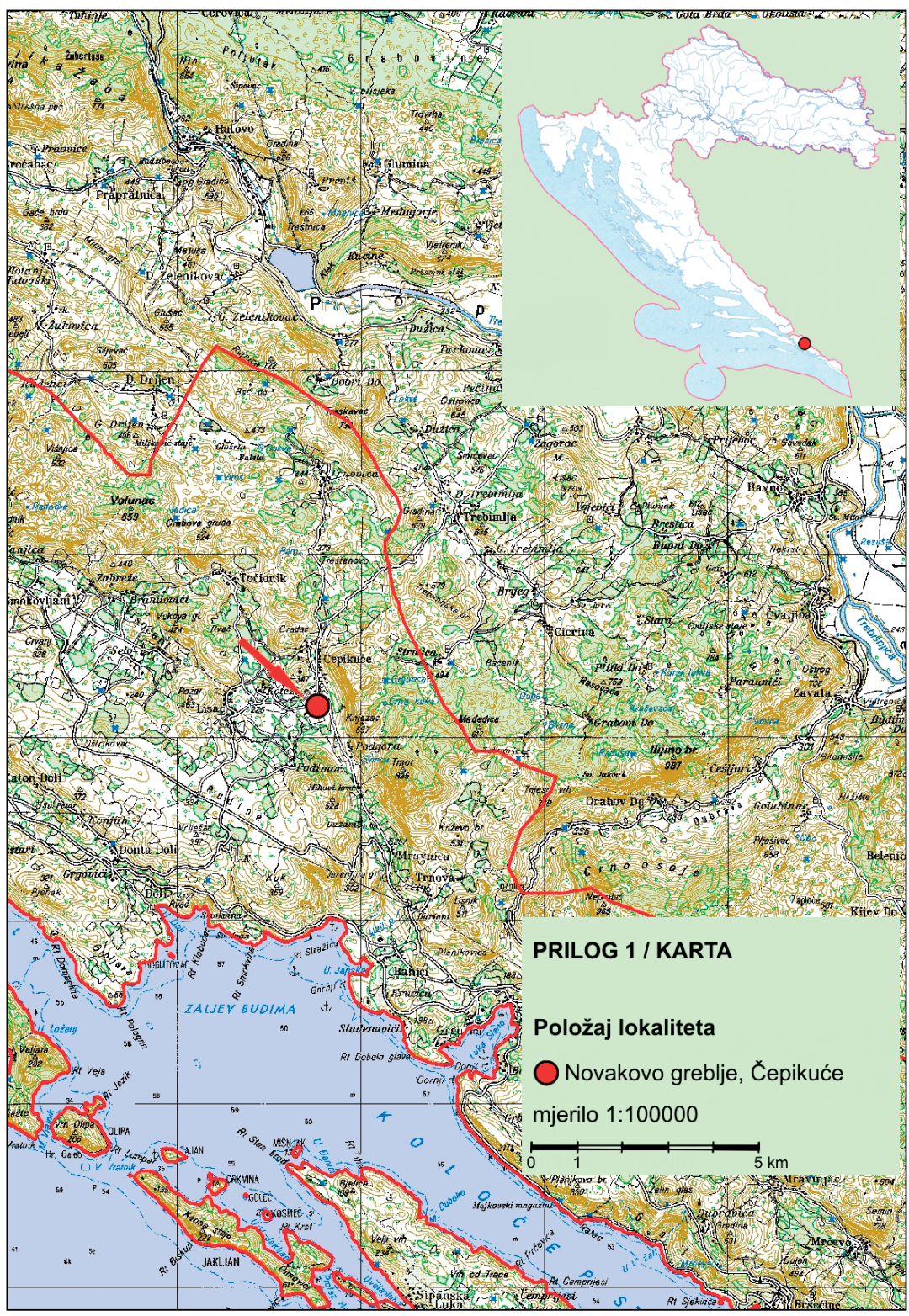

Prilog 1 - Karta s položajem lokaliteta Novakovo greblje (računalna obrada D. Perkić) 


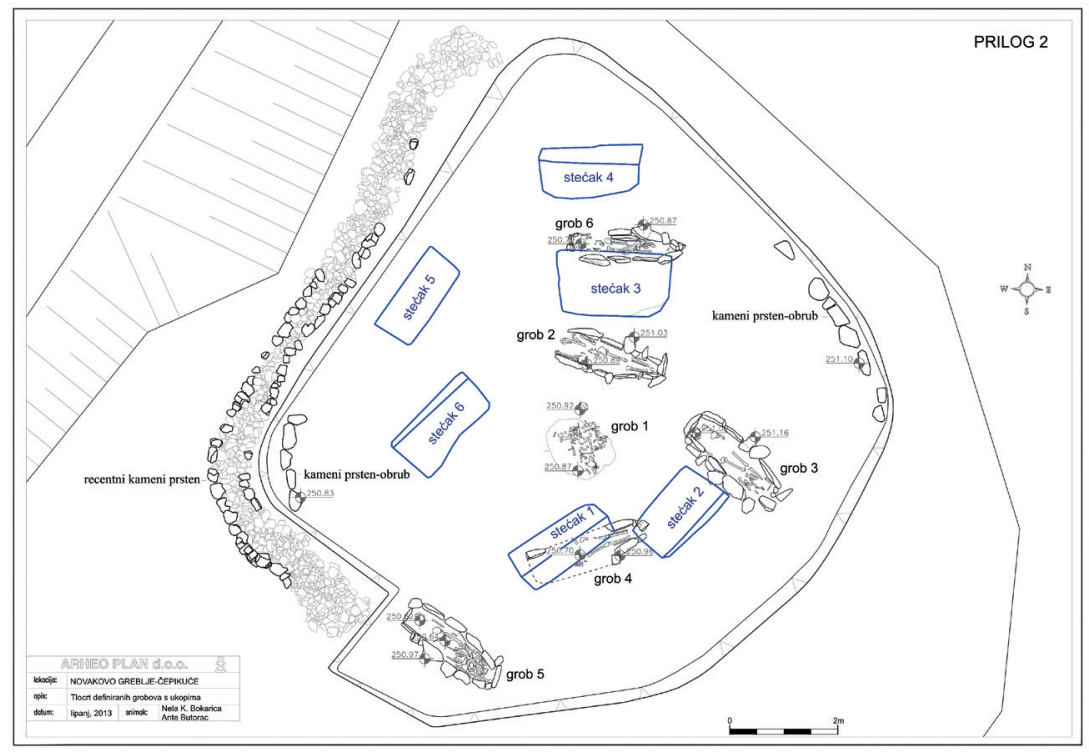

Prilog 2 - Tlocrt grobova s položajima stećaka (N. Kovačević Bokarica, A. Butorac, Arheoplan d.o.o.)

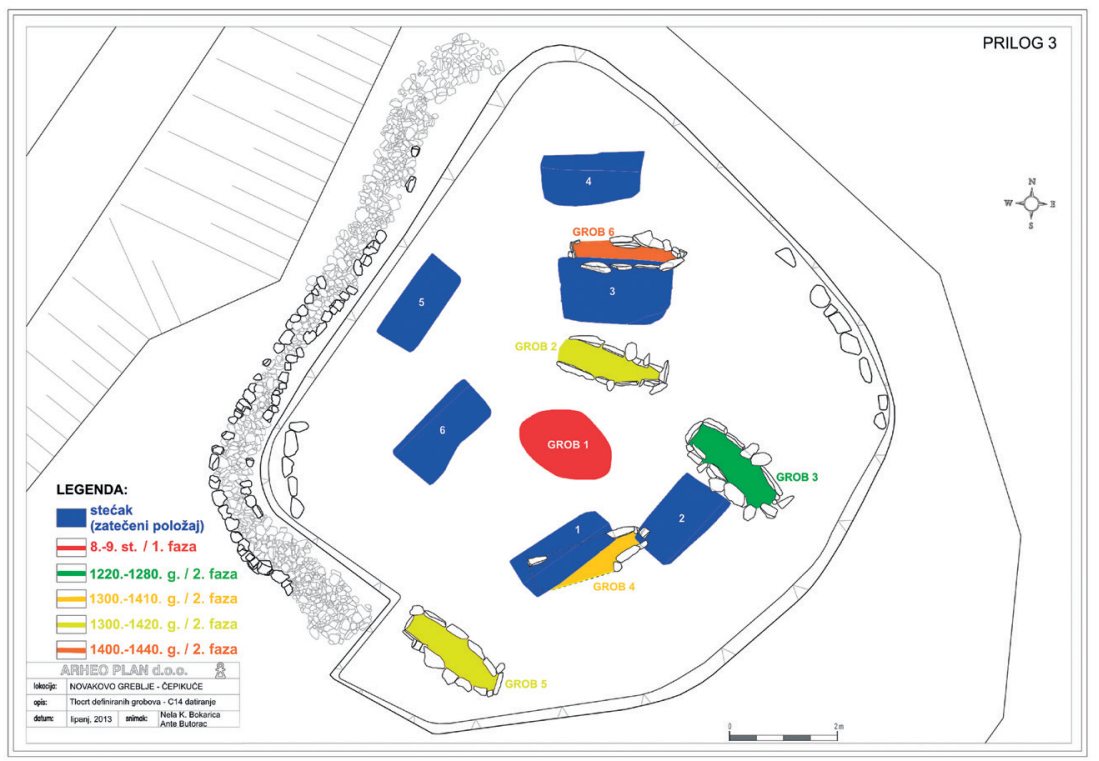

Prilog 3 - Tlocrt grobova i stećaka u odnosu na C-14 datiranje (N. Kovačević Bokarica, A. Butorac, Arheoplan d.o.o.) 
Domagoj Perkić - Stećci na području Dubrovačkoga primorja - nove spoznaje

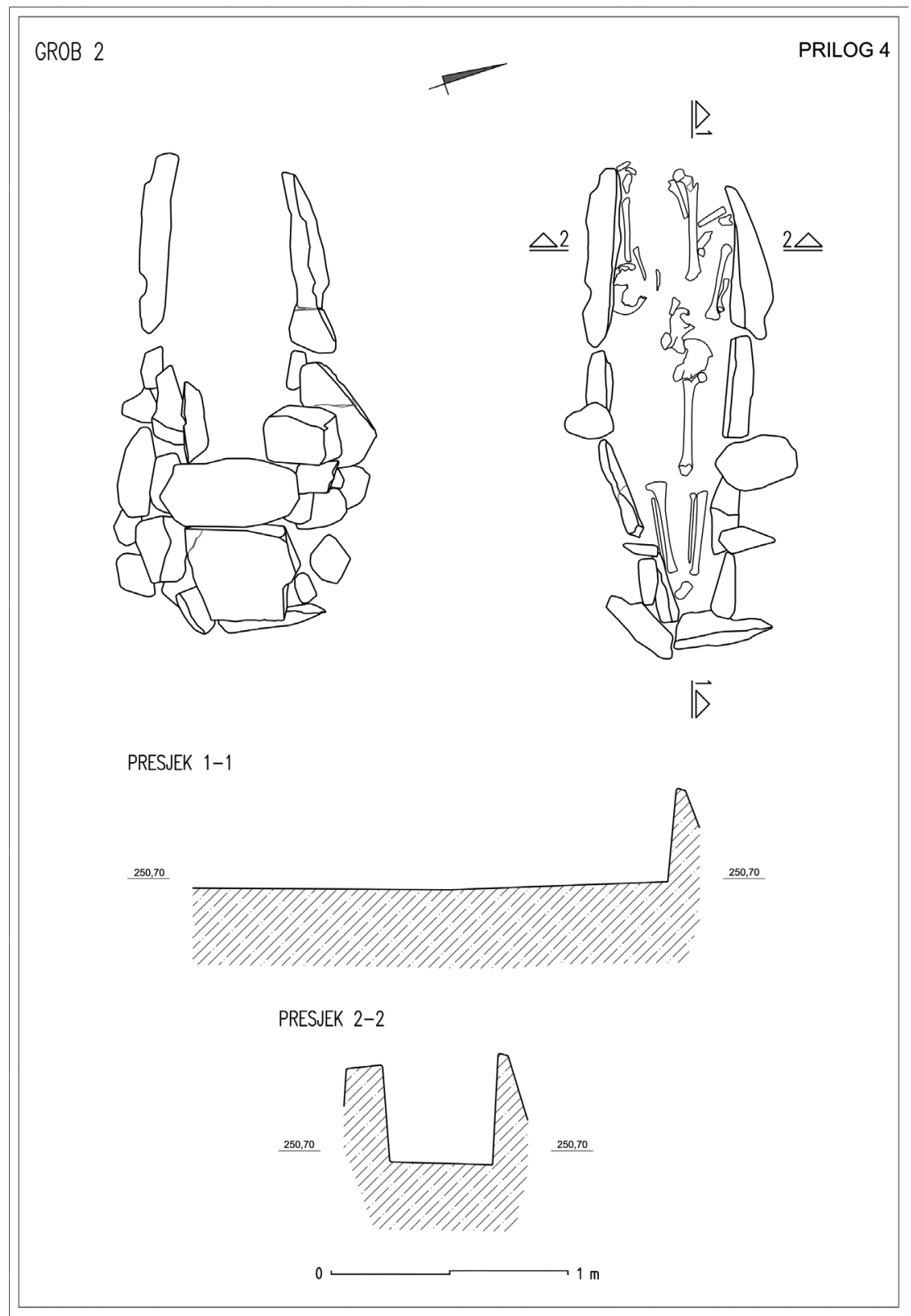

Prilog 4 - Tlocrt i presjek groba 2 (N. Kovačević Bokarica, A. Butorac, Arheoplan d.o.o.) 


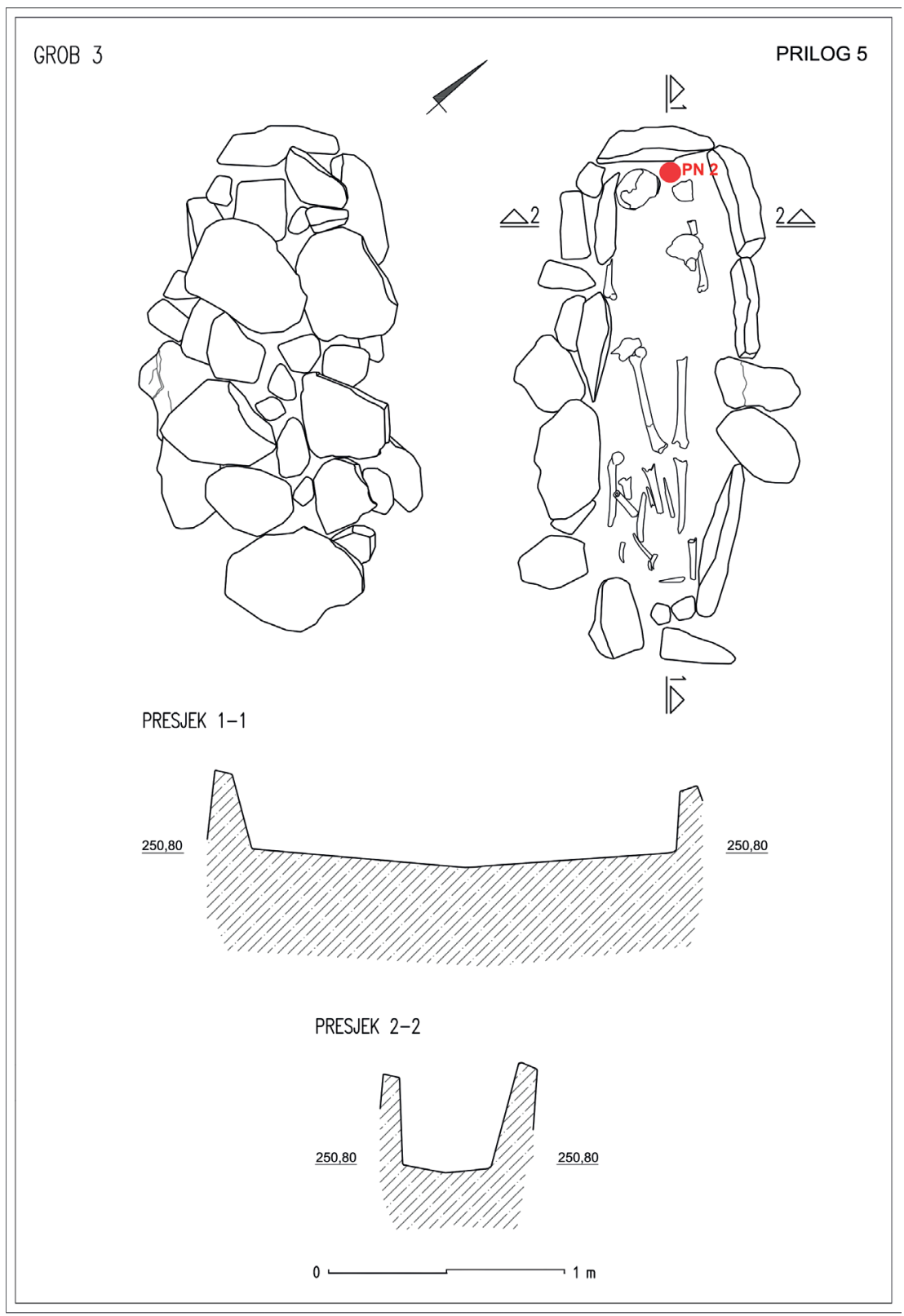

Prilog 5 - Tlocrt i presjek groba 3 (N. Kovačević Bokarica, A. Butorac, Arheoplan d.o.o.) 
Domagoj Perkić - Stećci na području Dubrovačkoga primorja - nove spoznaje

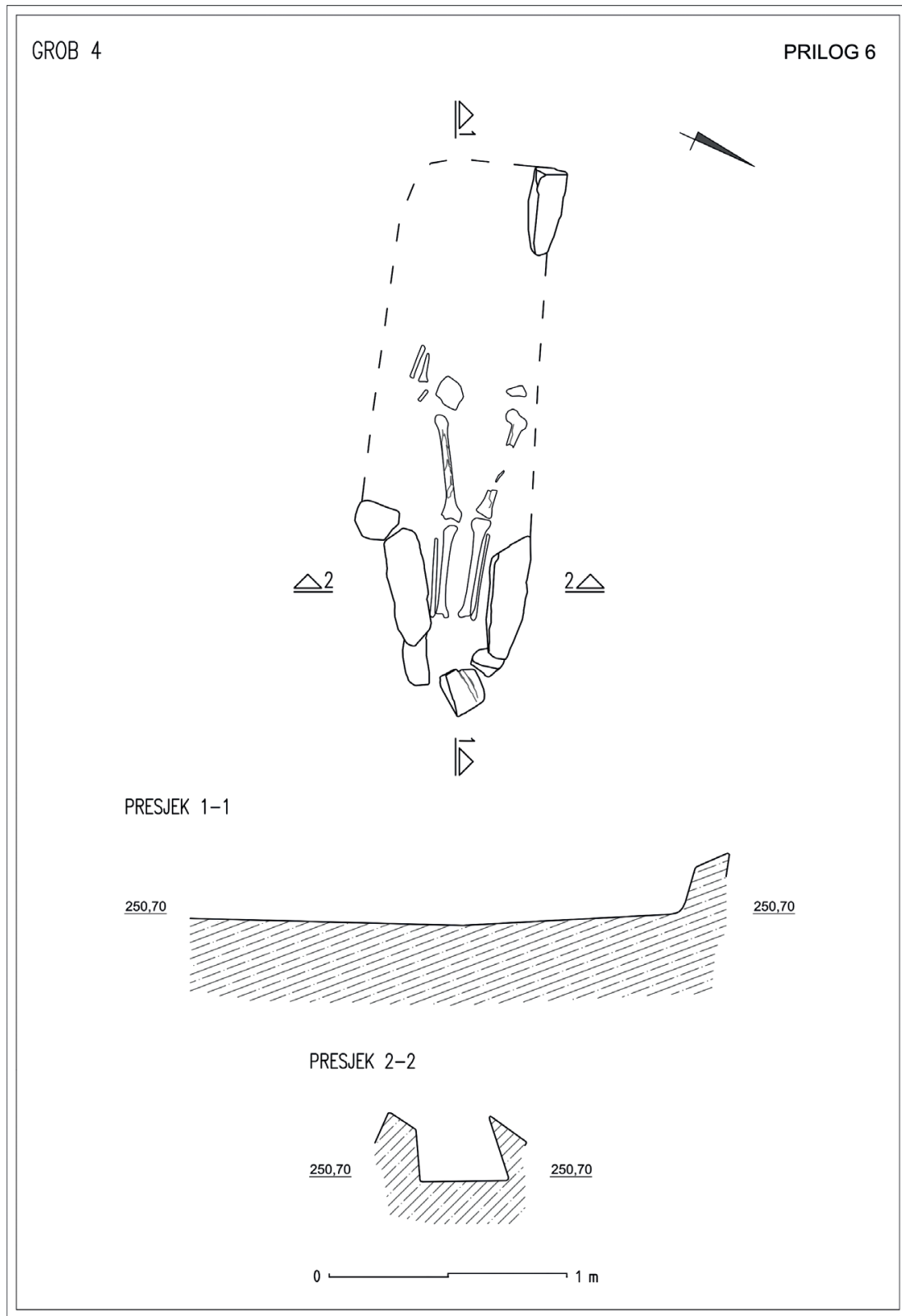

Prilog 6 - Tlocrt i presjek groba 5 (N. Kovačević Bokarica, A. Butorac, Arheoplan d.o.o.) 


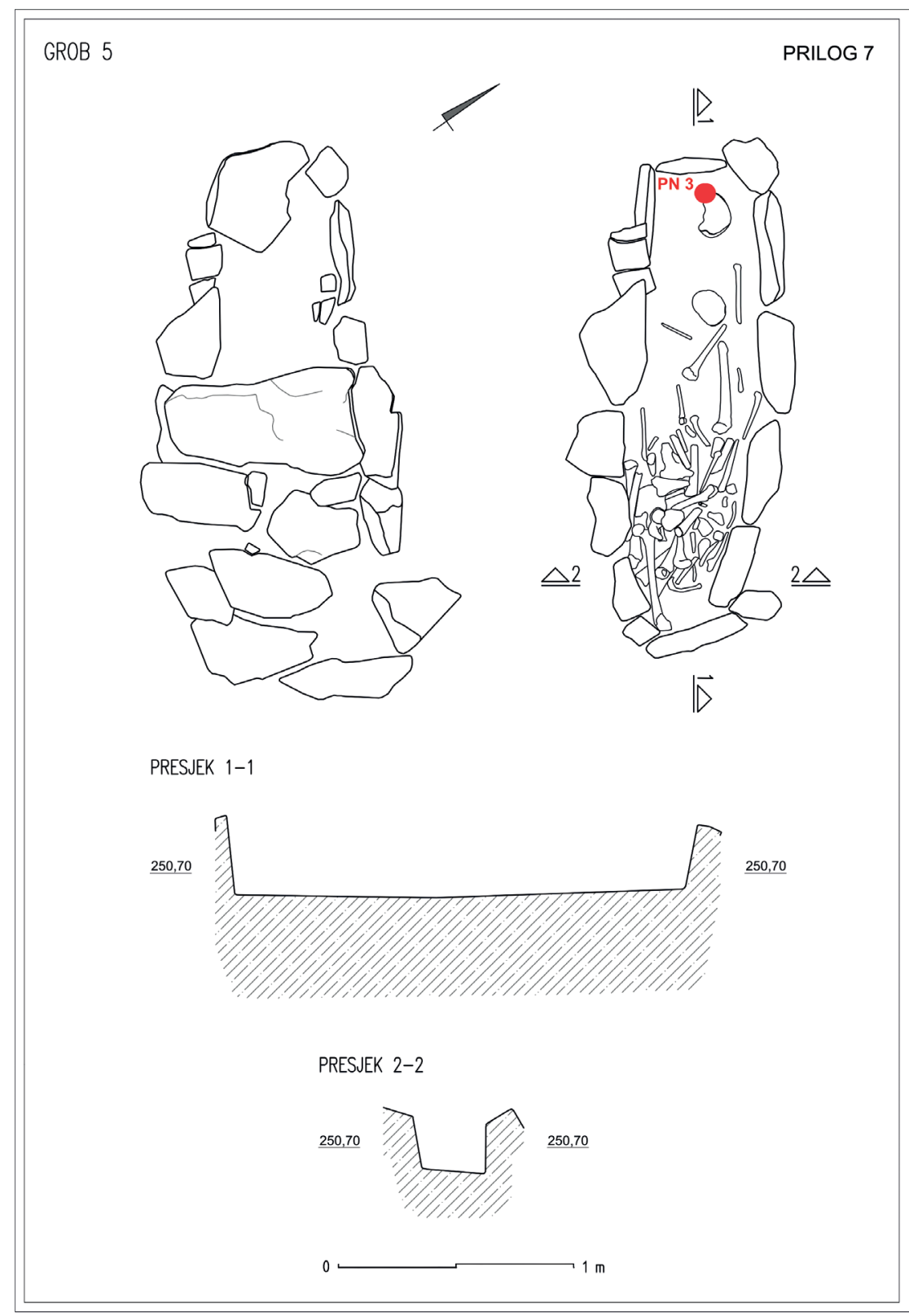

Prilog 7 - Tlocrt i presjek groba 5 (N. Kovačević Bokarica, A. Butorac, Arheoplan d.o.o.) 
Domagoj Perkić - Stećci na području Dubrovačkoga primorja - nove spoznaje

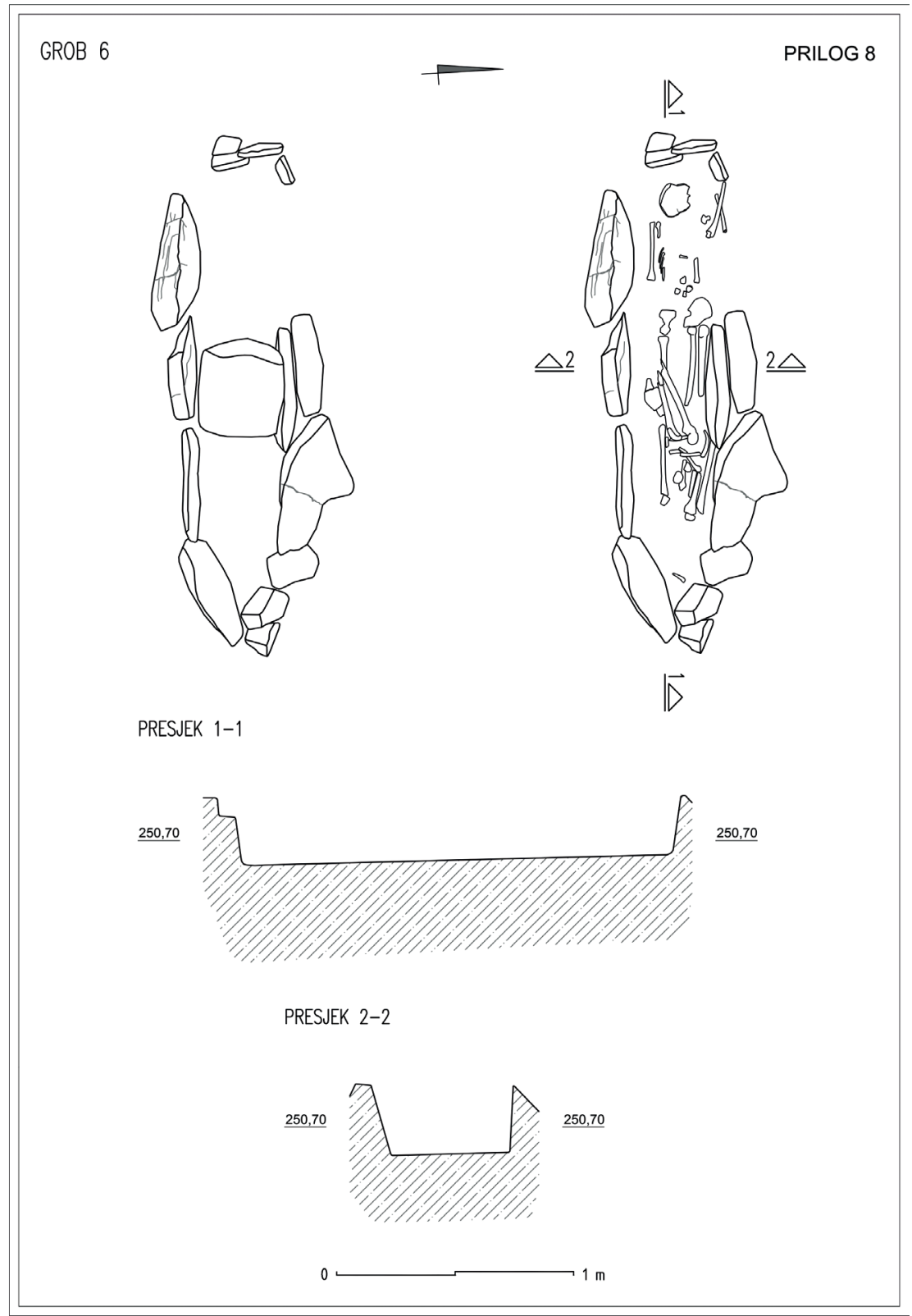

Prilog 8 - Tlocrt i presjek groba 6 (N. Kovačević Bokarica, A. Butorac, Arheoplan d.o.o.) 
Hercegovina - 6 - 2020., str. 19-61

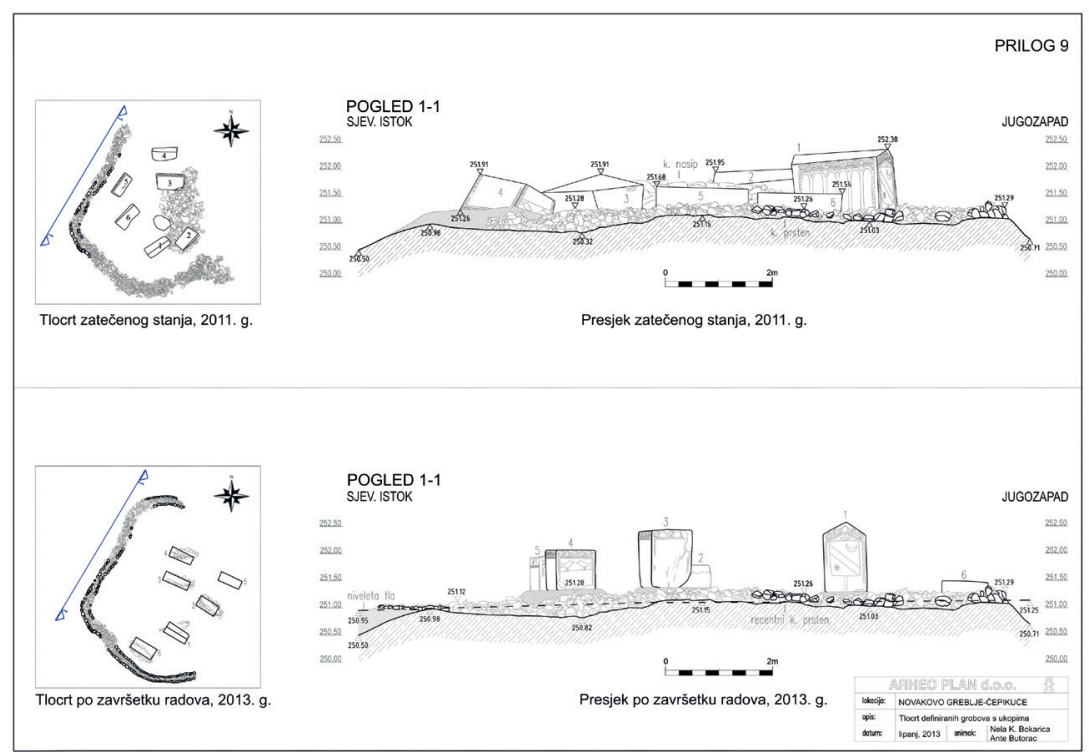

Prilog 9 - Presjek lokaliteta, prije i nakon radova (N. Kovačević Bokarica, A. Butorac, Arheoplan d.o.o.) 
Domagoj Perkić - Stećci na području Dubrovačkoga primorja - nove spoznaje

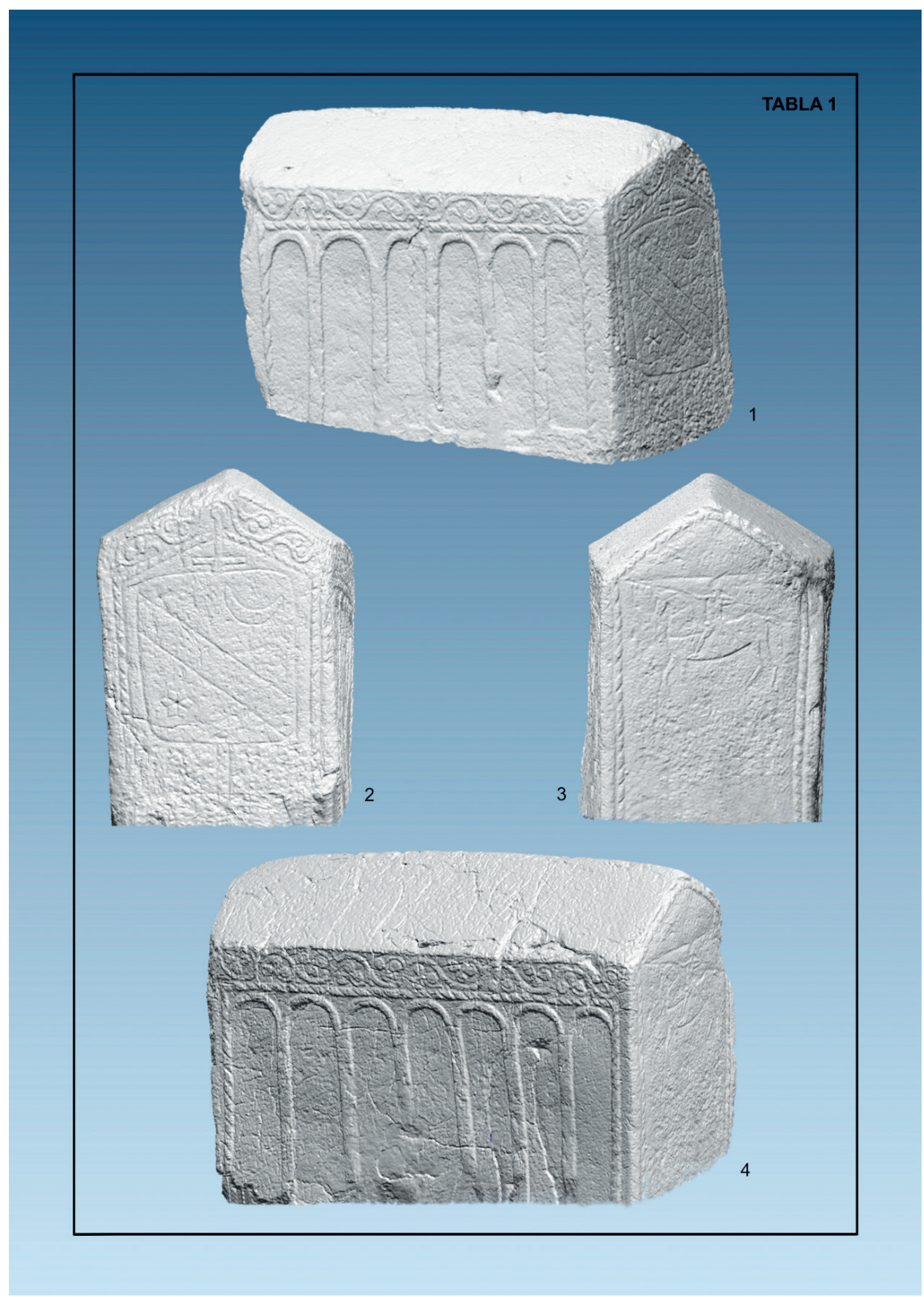

Tabla 1 - 3D snimak stećka 1 (Neir d.o.o., računalna obrada D. Perkić) 
Hercegovina - 6 - 2020., str. 19-61

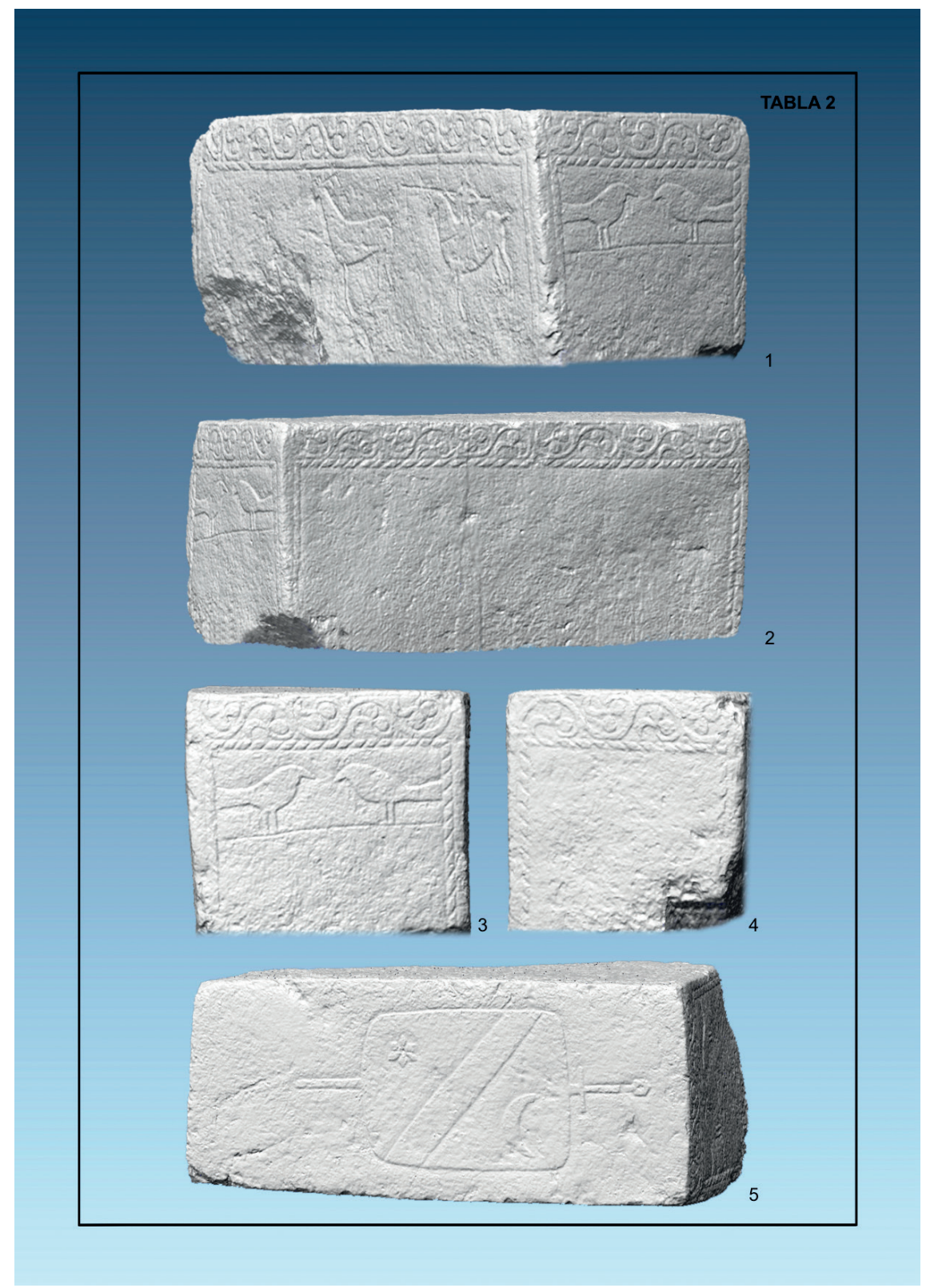

Tabla 2 - 3D snimak stećka 4 (Neir d.o.o., računalna obrada D. Perkić) 
Domagoj Perkić - Stećci na području Dubrovačkoga primorja - nove spoznaje

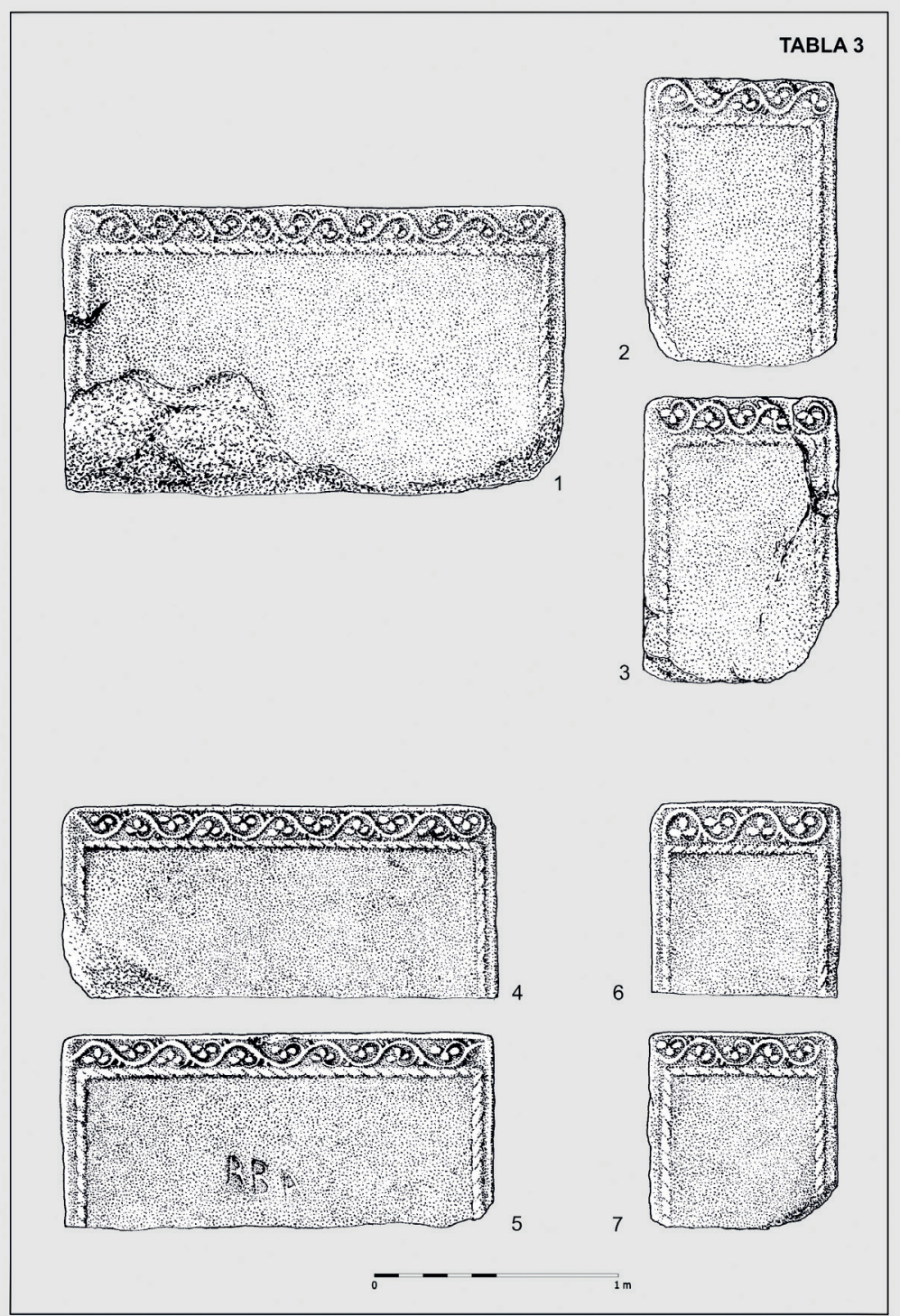

Tabla 3 - crtež stećka 3 i 5 (Marta Perkić, računalna obrada D. Perkić) 


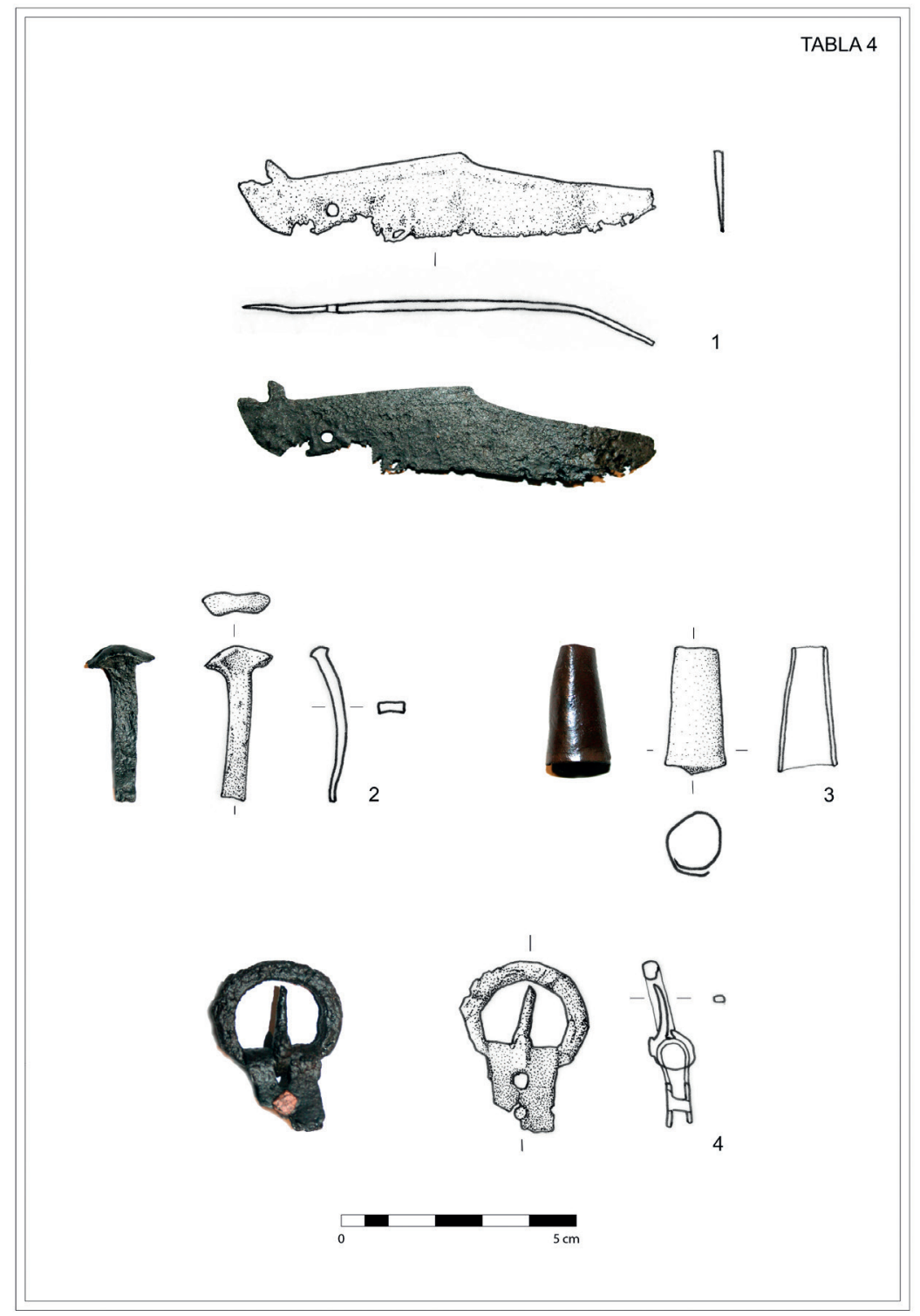

Tabla 4 - Fotografije i crteži posebnih nalaza 1-4 (crtež Mirna Jokić, računalna obrada D. Perkić) 


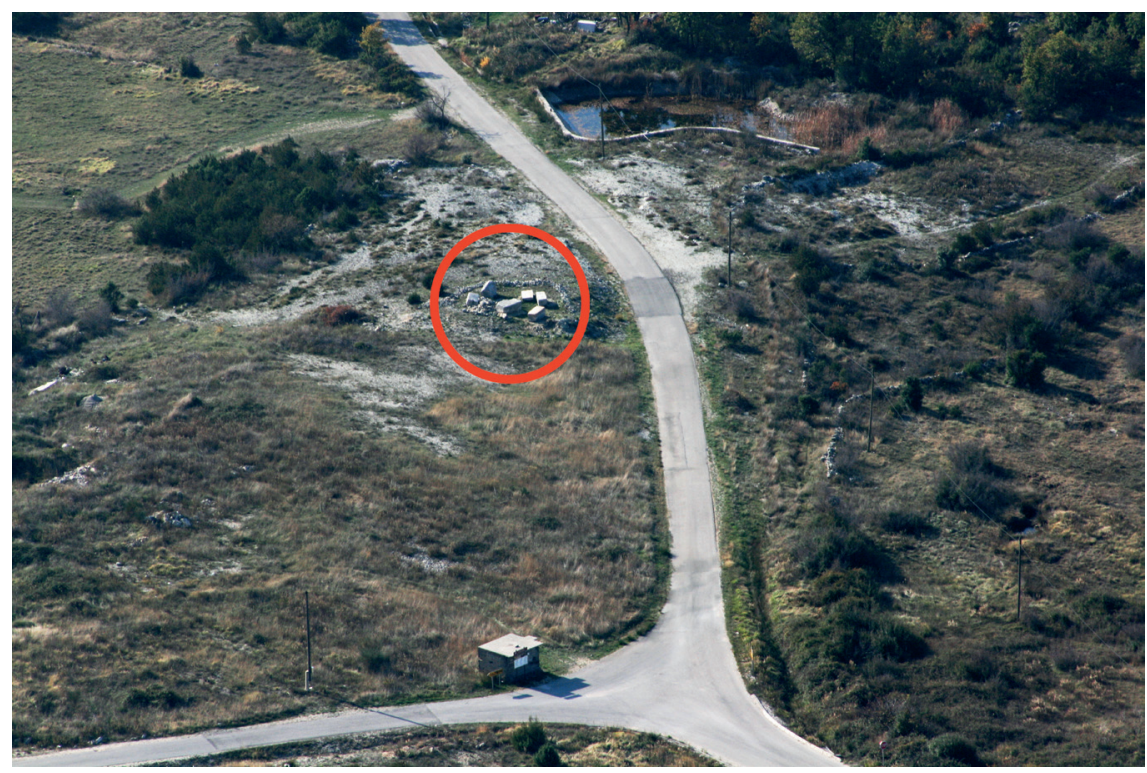

Slika 1 - pogled na Novakovo greblje sa sjevera (foto D. Perkić)

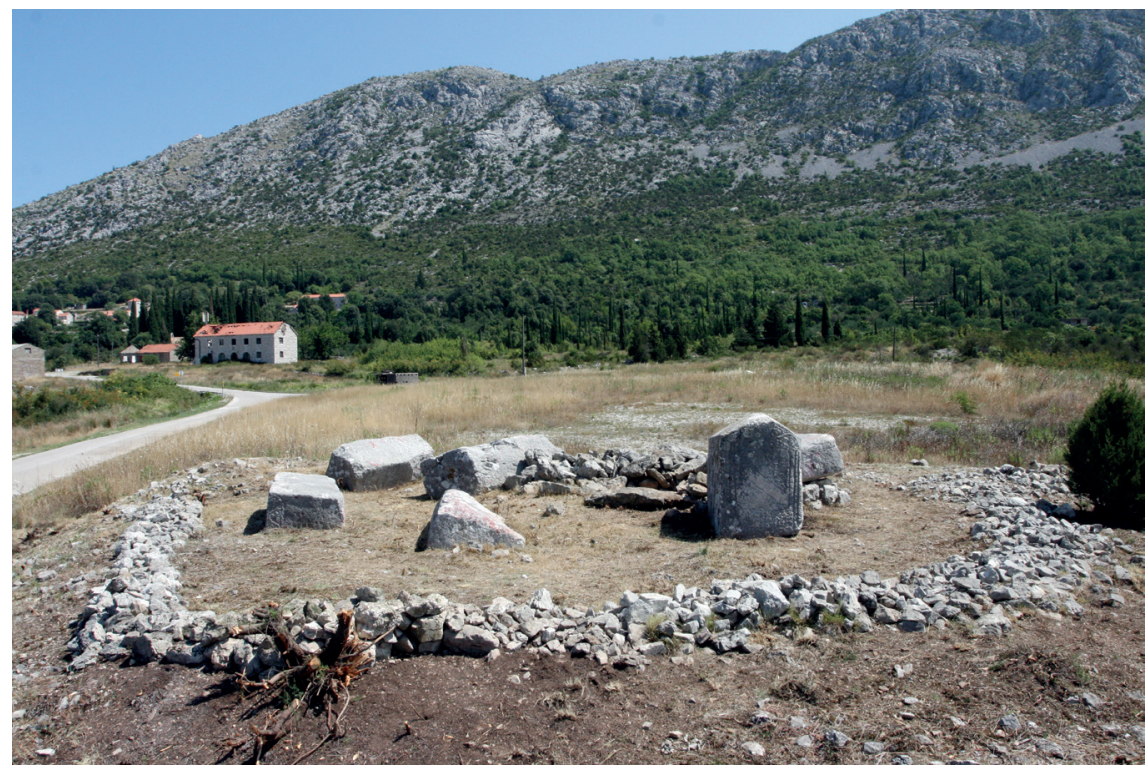

Slika 2 - pogled na Novakovo greblje s juga, stanje prije istraživanja (foto N. Kovačević Bokarica) 


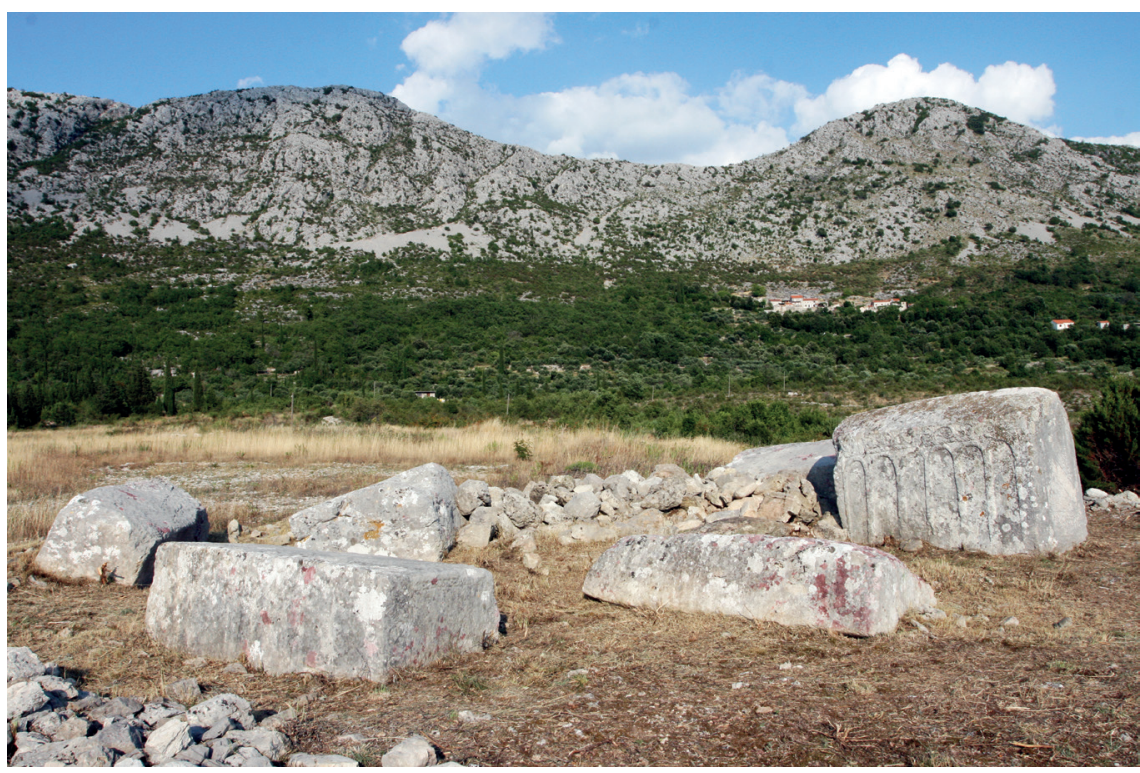

Slika 3 - pogled na Novakovo greblje sa zapada, stanje prije istraživanja (foto N. Kovačević Bokarica)

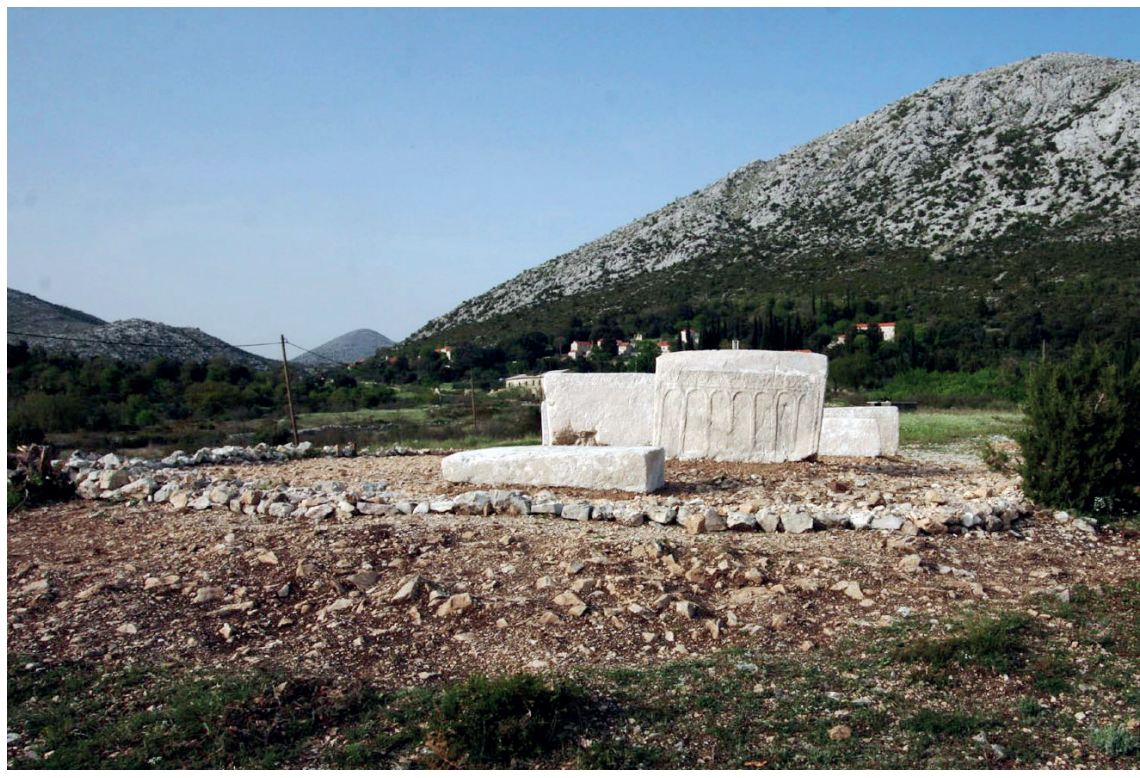

Slika 4 - pogled na Novakovo greblje s juga, stanje poslije istraživanja (foto N. Kovačević Bokarica) 


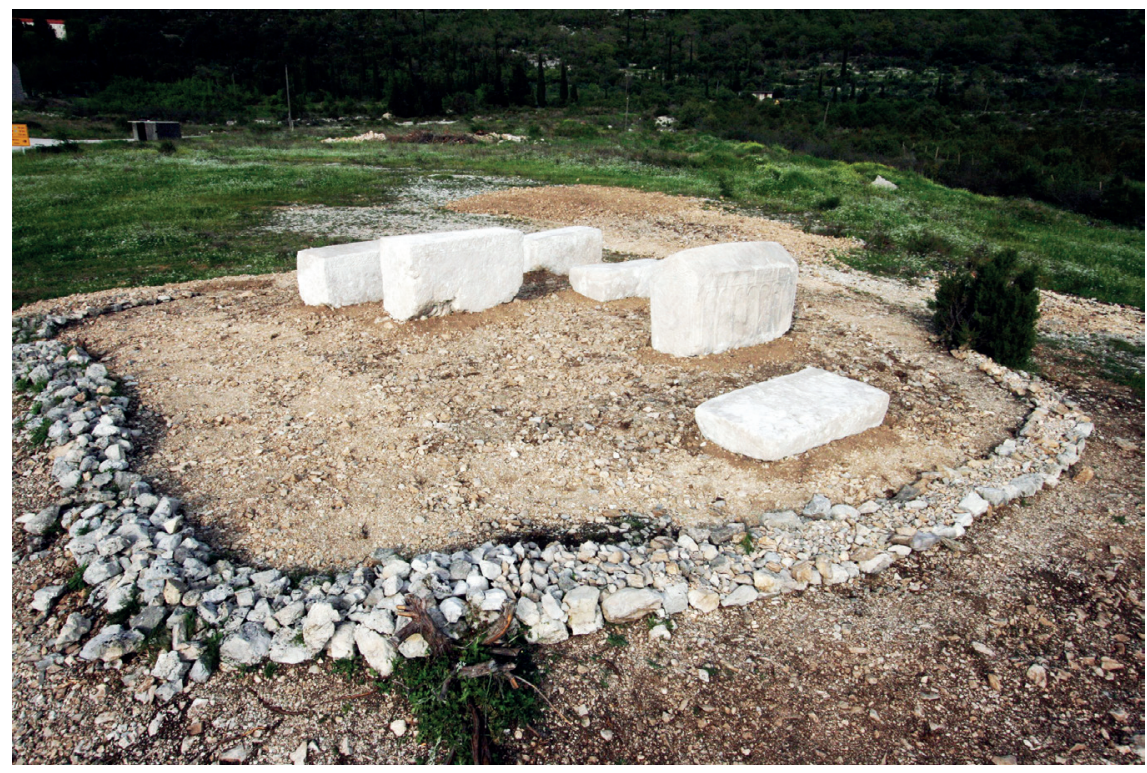

Slika 5 - pogled na Novakovo greblje s jugozapada, stanje poslije istraživanja (foto N. Kovačević Bokarica)

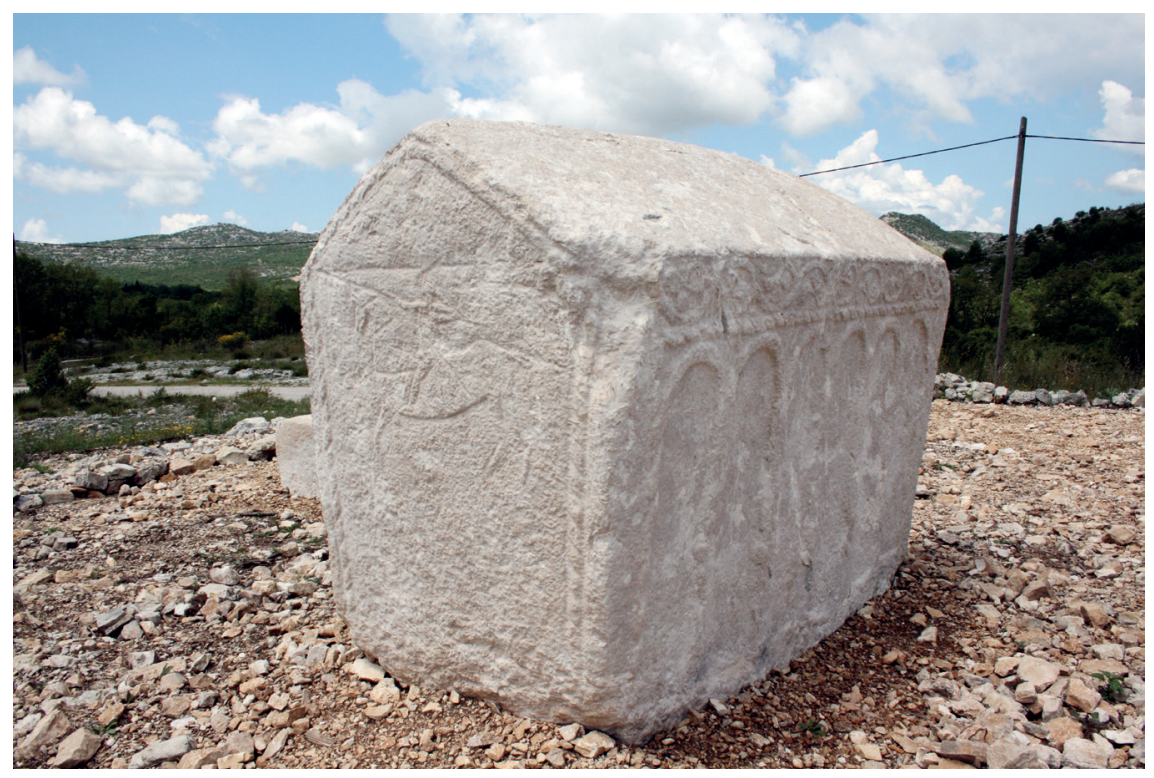

Slika 6 - stećak 1, nakon konzervacije (foto D. Perkić) 


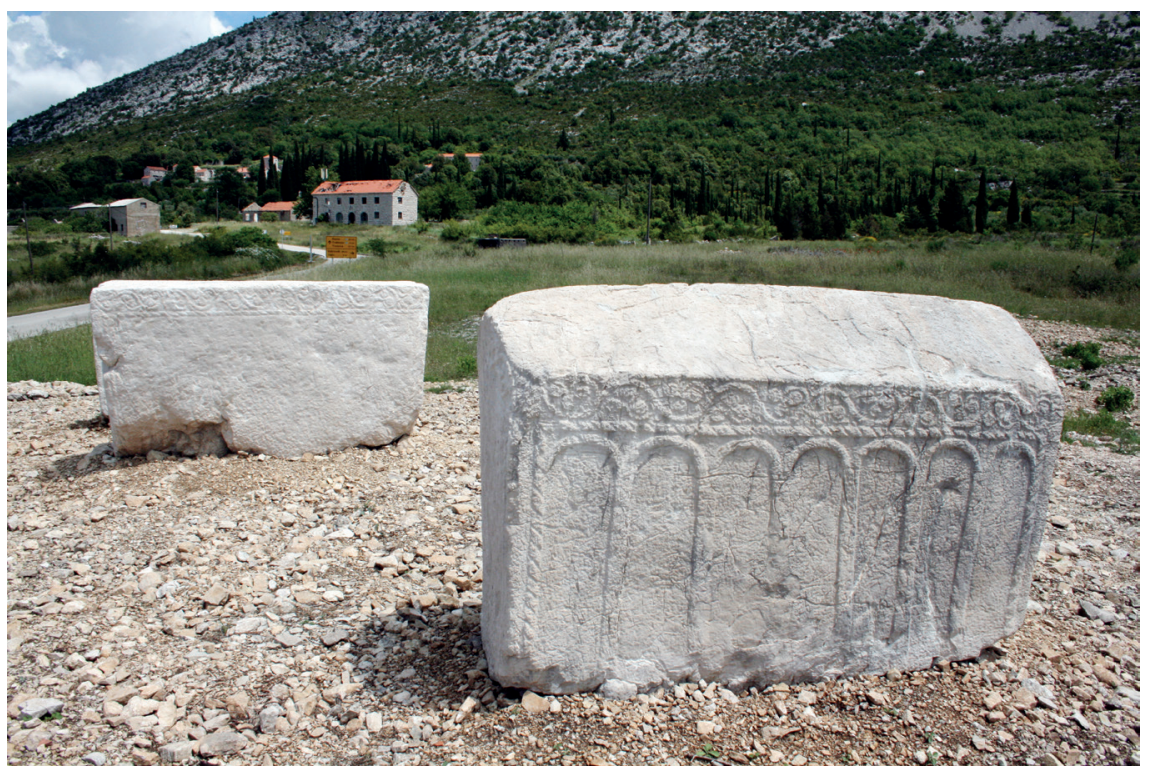

Slika 7 - stećak 1 i 4, nakon konzervacije (foto D. Perkić)

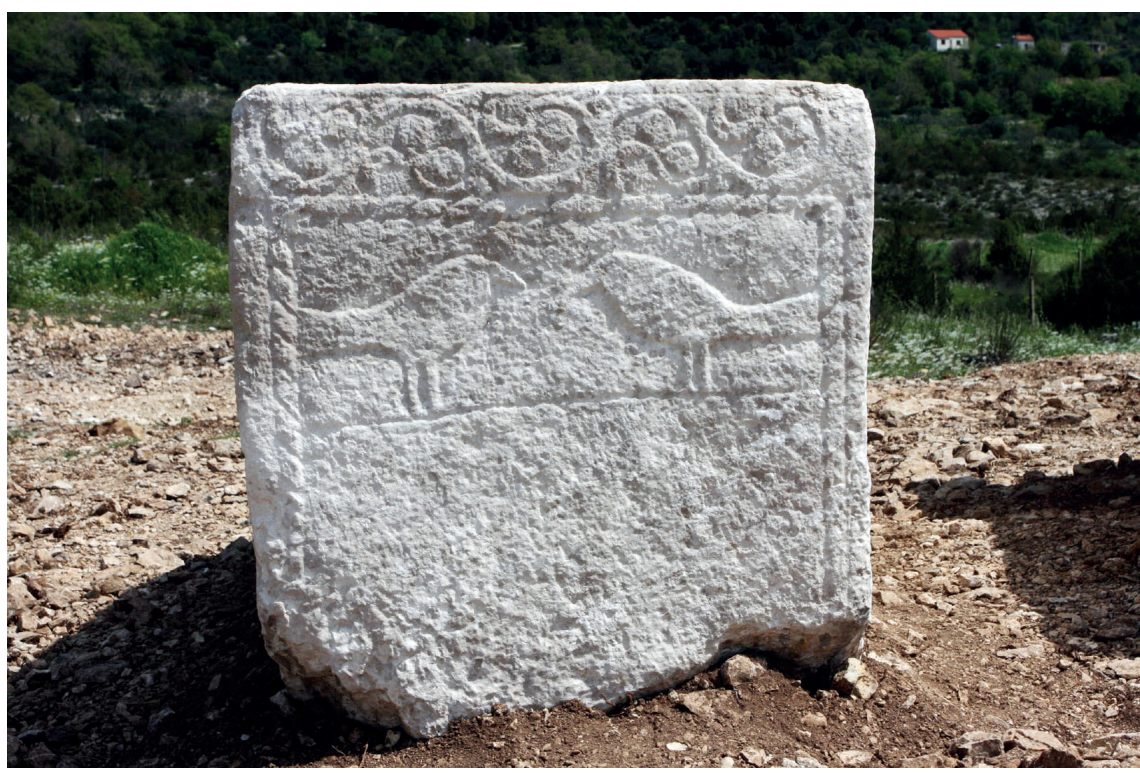

Slika 8 - stećak 4, nakon konzervacije (foto N. Kovačević Bokarica) 
Domagoj Perkić

Dubrovnik Museums

Archeological Museum

E-mail: domagoj.perkic@gmail.com
Original scientific article

Received: 27 February 2020

Accepted: 10 June 2020

\section{Stecaks in Dubrovnik Littoral - new findings}

\section{Summary}

Detailed survey of stecak sites in wider Dubrovnik region was published in the context of creating the catalogue for the exhibition "Stecaks" held in Klovicevi Dvori in Zagreb (2008) and later in the framework of the project "HER.CUL" (2010-2013) as well as in the publication of Dubrovnik Museums: Stecaks and other late medieval gravestones in the western Dubrovnik region (2018-2019). In this way the status of at least topographic and statistic data was updated. In that context, we can find stecaks in the area of Konavle Municipality (24 sites with 588 stecaks), Municipality of Zupa Dubrovacka (4 sites with 21 stecaks) administrative area of the City of Dubrovnik from Sumet in the east to Dubravica and Ridica in the West (10 sites with 68 stecaks) and Dubrovnik coastal area (29 sites with 362 stecaks). That would be 67 sites with 1039 stecaks in total.

Archaeological research as well as conservation and restoration of all stecaks at the site Novakovo Greblje in Cepikuce, Dubrovnik Littoral Municipality are also published in the framework of the mentioned project "HER.CUL". Archaeological excavations from 2013 showed that late medieval graveyard with stecaks was located at the position of the former graveyard from the 8th/9th century AD. Cluster of bones (of at least 10 individuals) was the only leftover from the former graveyard and it was located in the central part of the site. As far as the graveyard with stecaks is concerned there were 6 stecaks and 5 graves with 15 buried individuals in total. According to the results of C-14 analysis graveyard was used from the first half of the 13th century to the second half of the 15th century. Only one woman was buried in the period from 1300 to 1400 under the biggest and most beautiful stecak, gabled tombstone, decorated by the shield and sworn and illustration of a horseman. That is a very valuable information for us, because we can place the emergence of the gabled 
tombstone in that period. Question of possible continuation of burying under stecaks after Dubrovnik Littoral became a part of Dubrovnik Republic in 1399, is also solved. It was determined that at least two burials had been performed in the 15th century. Although Novakovo Greblje is for the time being the only systematically archaeologically researched graveyard with stecaks in Dubrovnik region, it can be assumed that burying under stecaks was continued independently of changes in the government and ruling with certain areas. In any case, those are extremely valuable remnants of the late Middle Ages cultural heritage, which complete knowledge of stecaks culture, not only in Dubrovnik but also wider region.

Keywords: stecaks; Dubrovnik Littoral; Cepikuce; Novakovo Greblje; topography; archaeological excavation; conservation. 